\title{
Global source attribution of sulfate concentration and direct and indirect radiative forcing
}

\author{
Yang Yang ${ }^{1}$, Hailong Wang ${ }^{1}$, Steven J. Smith ${ }^{2}$, Richard Easter ${ }^{1}$, Po-Lun Ma ${ }^{1}$, Yun Qian ${ }^{1}$, Hongbin $\mathbf{Y u}^{3}$, Can Li ${ }^{3,4}$, \\ and Philip J. Rasch ${ }^{1}$ \\ ${ }^{1}$ Atmospheric Science and Global Change Division, Pacific Northwest National Laboratory, Richland, Washington, USA \\ ${ }^{2}$ Joint Global Change Research Institute, Pacific Northwest National Laboratory, College Park, Maryland, USA \\ ${ }^{3}$ NASA Goddard Space Flight Center, Greenbelt, Maryland, USA \\ ${ }^{4}$ Earth System Science Interdisciplinary Center, University of Maryland, College Park, Maryland, USA
}

Correspondence to: Yang Yang (yang.yang@pnnl.gov) and Hailong Wang (hailong.wang@pnnl.gov)

Received: 31 March 2017 - Discussion started: 4 April 2017

Revised: 19 June 2017 - Accepted: 25 June 2017 - Published: 25 July 2017

\begin{abstract}
The global source-receptor relationships of sulfate concentrations, and direct and indirect radiative forcing (DRF and IRF) from 16 regions/sectors for years 2010 2014 are examined in this study through utilizing a sulfur source-tagging capability implemented in the Community Earth System Model (CESM) with winds nudged to reanalysis data. Sulfate concentrations are mostly contributed by local emissions in regions with high emissions, while over regions with relatively low $\mathrm{SO}_{2}$ emissions, the near-surface sulfate concentrations are primarily attributed to non-local sources from long-range transport. Regional source efficiencies of sulfate concentrations are higher over regions with dry atmospheric conditions and less export, suggesting that lifetime of aerosols, together with regional export, is important in determining regional air quality. The simulated global total sulfate DRF is $-0.42 \mathrm{~W} \mathrm{~m}^{-2}$, with $-0.31 \mathrm{~W} \mathrm{~m}^{-2}$ contributed by anthropogenic sulfate and $-0.11 \mathrm{~W} \mathrm{~m}^{-2}$ contributed by natural sulfate, relative to a state with no sulfur emissions. In the Southern Hemisphere tropics, dimethyl sulfide (DMS) contributes $17-84 \%$ to the total DRF. East Asia has the largest contribution of $20-30 \%$ over the Northern Hemisphere mid- and high latitudes. A $20 \%$ perturbation of sulfate and its precursor emissions gives a sulfate incremental IRF of $-0.44 \mathrm{~W} \mathrm{~m}^{-2}$. DMS has the largest contribution, explaining $-0.23 \mathrm{~W} \mathrm{~m}^{-2}$ of the global sulfate incremental IRF. Incremental IRF over regions in the Southern Hemisphere with low background aerosols is more sensitive to emission perturbation than that over the polluted Northern Hemisphere.
\end{abstract}

\section{Introduction}

Sulfate is an important aerosol that poses health risks (Fajersztajn et al., 2013; Xu et al., 2013), and sulfur deposition is a major driver of ecosystem acidification (Driscoll et al., 2010). Due to long-range transport, local sulfate pollution could result from intercontinental influences, making domestic efforts of improving air quality inefficient (Park et al., 2004; Bergin et al., 2005; Liu and Mauzerall, 2007). In addition, sulfate aerosol substantially perturbs the radiation budget of the Earth directly through scattering incoming solar radiation and indirectly through modifying cloud microphysical properties (Lohmann and Feichter, 2005; Stevens and Feingold, 2009; Myhre et al., 2013). On a global average basis, anthropogenic sulfate aerosol contributes a negative direct radiative forcing (DRF) of $-0.4 \pm 0.2 \mathrm{~W} \mathrm{~m}^{-2}$ (Boucher et al., 2013). The negative radiative forcing from sulfate partly offsets the positive radiative forcing from greenhouse gases. Therefore, accurate understanding of source attribution of sulfate and its radiative forcing is important for both regional air quality and global climate mitigation (Shindell et al., 2012), which are of great interest to not only the science community but also the general public and policymakers.

Sulfate aerosol is produced through oxidation of sulfur dioxide $\left(\mathrm{SO}_{2}\right)$ by the hydroxyl radical $(\mathrm{OH})$ in gas-phase and aqueous-phase oxidation mainly by hydrogen peroxide $\left(\mathrm{H}_{2} \mathrm{O}_{2}\right)$ (Martin and Damschen, 1981). The $\mathrm{SO}_{2}$ precursor is mainly emitted from fossil-fuel combustion ( $\mathrm{Lu}$ et al., 2010). In recent decades, $\mathrm{SO}_{2}$ emissions from many devel- 
oping countries in East and South Asia have increased substantially as a result of accelerated urbanization and rapid economic growth (Streets et al., 2000; Pham et al., 2005). In contrast, due to air pollution regulations, $\mathrm{SO}_{2}$ emissions in North America and Europe have decreased significantly since 1980-1990 (Smith et al., 2011; Prechtel et al., 2001). As a consequence, source attribution of sulfate has changed with time over recent decades.

Previous studies have reported that regional aerosols, including sulfate, are produced not only by domestic emissions but also by distant sources through long-range transport (Jacob et al., 2003; Jaffe et al., 2003; Park et al., 2004; Heald et al., 2006; Liu et al., 2008, 2009; Yu et al., 2012). For example, the strong anthropogenic emissions over East Asia have led to an increasing interest in quantifying the impact of aerosols exported from East Asia. Recent studies indicate that the transpacific transport of sulfate from East Asia contributes to $30-50 \%$ of the background (sulfate produced from non-local emissions) surface concentrations in the western US and 10-30\% in the eastern US (Park et al., 2004; Hadley et al., 2007; Liu et al., 2008), which are larger than contributions from all other foreign sources (Liu et al., 2009). In addition, among the major emitting regions assessed for 2001 conditions, European sources were shown to account for $1-5 \mu \mathrm{g} \mathrm{m}^{-3}$ of surface sulfate concentrations over northern Africa and western Asia, and their contribution to East Asia $\left(0.2-0.5 \mu \mathrm{g} \mathrm{m}^{-3}\right)$ was twice as much as the contribution $\left(0.1-0.2 \mu \mathrm{g} \mathrm{m}^{-3}\right)$ of Asian sources to North America (Chin et al., 2007).

Due to the important role of sulfate aerosol in the climate system, knowing the relative significance of sulfate radiative forcing from different source regions is useful for climate mitigation. Some previous studies examined the impact of emission reductions on global and regional DRF and the influence of long-range transport (Yu et al., 2013; Bellouin et al., 2016; Stjern et al., 2016). Yu et al. (2013) examined changes in aerosol DRF resulting from a $20 \%$ reduction in anthropogenic emissions from four major polluted regions (namely North America, Europe, East Asia and South Asia) in the Northern Hemisphere, using simulations by nine models from the first phase of the Hemispheric Transport of Air Pollution (HTAP1). They found that $31 \%$ of South Asia sulfate aerosol optical depth over South Asia was contributed by non-local sources. Based on the HTAP2, Stjern et al. (2016), using results from 10 models, further assessed global and regional DRF from a $20 \%$ reduction in emissions over seven regions including North America, Europe, South Asia, East Asia, Russia, the Middle East and the Arctic. They found that the $20 \%$ reduction in emissions in South Asia and East Asia largely perturbed the radiative balance for other regions. However, these studies focused on only the limited number of source regions over the Northern Hemisphere. Continents and subcontinents over the tropics and Southern Hemisphere are also important source and receptor regions for the sulfate radiative forcing, especially for indirect forcing due to stronger aerosol-cloud interactions in clean environments (Koren et al., 2014). Bellouin et al. (2016) quantified the radiative forcing efficiency based on simulations of a $20 \%$ reduction in emissions from four source regions/sectors in year 2008, and reported that, with aerosol-cloud interactions included, models simulated higher radiative forcing efficiency of sulfate compared to previous studies (Myhre et al., 2013; Shindell et al., 2013; Yu et al., 2013). Few studies have quantified systematically the global source-receptor relationships of sulfate indirect radiative forcing that can be attributed to local/non-local source regions and anthropogenic/natural source sectors.

This is the first study that examines source attribution of sulfate radiative forcing with both anthropogenic and natural sources covering the whole globe. In this study, we introduce an explicit sulfur source-tagging technique into the Community Earth System Model (CESM), in which sulfate aerosol and its precursor emissions from 16 source regions/sectors (14 major source regions and 2 natural source sectors) are tagged and explicitly tracked. This method allows us to efficiently quantify source region/sector contributions to regional and global sulfate mass concentrations, and to direct and indirect radiative forcing (DRF and IRF) of sulfate.

Model description, emissions data sets and model experiments are shown in Sect. 2. Section 3 gives the comparison of modeled concentrations of sulfate and $\mathrm{SO}_{2}$ with a variety of observations. Section 4 shows model results for source attributions of near-surface sulfate concentrations over various receptor regions. Source attributions of DRF and IRF of sulfate are discussed in Sect. 5. Section 6 summarizes all the results and main conclusions.

\section{Methods}

\subsection{Model description}

We use the version 5 of the Community Atmosphere Model (CAM5), which is the atmospheric component of CESM (Hurrell et al., 2013), to simulate the sulfate aerosol and calculate its DRF and IRF. The modal aerosol treatment in CAM5 (Liu et al., 2012) predicts number mixing ratios and mass mixing ratios of aerosols, distributed in three lognormal modes. A set of modifications to CAM5 that improves wet scavenging of aerosols and convective transport reported by Wang et al. (2013) has also been implemented in the model used in this study. Sulfate is internally mixed with other species in the same aerosol mode and then externally mixed between modes. Sulfate refractive indices at visible wavelengths is $1.43+0.00 i$. Activation of cloud droplets uses the scheme from Abdul-Razzak and Ghan (2000). The model simulates aerosol-cloud interactions in stratiform clouds using a physically based two-moment parameterization (Morrison and Gettelman, 2008). In addition to the standard radiative fluxes calculated in the model by taking into account 
all aerosols, the CESM has the capability of diagnosing radiative fluxes in parallel for a subset of aerosol species. The difference between the standard and the diagnosed radiative fluxes can then be attributed to the difference in aerosols considered in the radiation calculations. For example, the difference in shortwave radiation fluxes at the top of the atmosphere (TOA) represents the DRF of the excluded aerosol components in the diagnostic calculation (Ghan, 2013). Using this same method, the DRF of sulfate from any of the 16 individual tagged regions/sectors can be derived from a pair of diagnostic radiation calculations with and without the particular tagged sulfate considered. To estimate IRF of sulfate from different sources, we define in this study an incremental IRF, calculated as $\Delta\left(F_{\text {clean }}-F_{\text {clear,clean }}\right)$, where $F$ is the radiative flux at TOA, $F_{\text {clean }}$ is the flux calculated neglecting scattering and absorption by aerosols, $F_{\text {clear,clean }}$ is the flux calculated neglecting scattering and absorption by both clouds and aerosols and $\Delta$ refers to the differences between the base and emission-perturbed simulations. Previous work found that the model did quite well at producing a reasonable sensitivity of number of cloud droplets to sulfate mass concentrations, reproducing a significant fraction of the MODIS climatological variability of cloud droplet number concentrations (McCoy et al., 2017). Note that the model only considers aerosol effects on stratiform cloud (Morrison and Gettelman, 2008), and no microphysical impact on convective clouds is included in the present version.

\subsection{Sulfur source tagging}

To quantify the regional source attributions of sulfate, for the first time, we implemented in CESM/CAM5 a sulfur sourcetagging capability, similar to the black carbon source-tagging method used in H. Wang et al. (2014) and Yang et al. (2017), through which sulfur gases and sulfate aerosols produced by emissions from independent sources are tagged. The tool can be used to quantify the source attributions of $\mathrm{SO}_{2}$ and sulfate without perturbing source emissions. The sulfur sourcetagging requires tagging of interstitial and cloud-borne sulfate in each of the three modes as well as $\mathrm{SO}_{2}, \mathrm{H}_{2} \mathrm{SO}_{4}$ and dimethyl sulfide (DMS) gases. In this study, sulfur species produced by emissions from 14 geographical source regions and 2 natural source sectors including volcanic eruptions and DMS from oceans are tagged. The tagged and un-tagged models have been verified to produce the same $\mathrm{SO}_{2} /$ sulfate properties and meteorology (Fig. S1 in the Supplement). While emissions of organic carbon, black carbon, sulfate and its precursor gases are all included in the simulations, the source tagging is used for sulfate and its precursor gases emissions alone.

\subsection{Emissions}

The CEDS (Community Emissions Data System) anthropogenic emissions (Hoesly et al., 2017) and open biomass burning emissions from van Marle et al. (2017) that were produced for the CMIP6 model experiments are used in our simulations. In CAM5, $97.5 \%$ of $\mathrm{SO}_{2}$ is emitted directly into the atmosphere and $2.5 \%$ is emitted as sulfate aerosol. Natural emissions of volcanic $\mathrm{SO}_{2}$ and DMS are the same as those used in AeroCom following Neale et al. (2012), which are kept constant throughout the selected years in this study. Figure 1a shows the 14 geographical source regions tagged in this study, which are consistent with source-receptor regions defined in HTAP2, including North America (NAM), Central America (CAM), South America (SAM), Europe (EUR), North Africa (NAF), Southern Africa (SAF), the Middle East (MDE), Southeast Asia (SEA), Central Asia (CAS), South Asia (SAS), East Asia (EAS), Russia/Belarus/Ukraine (RBU), Pacific/Australia/New Zealand (PAN) and rest of the world (ROW, including oceans and polar continents). Table 1 summarizes emissions of combustion $\mathrm{SO}_{2}$ (anthropogenic + open biomass burning), volcanic $\mathrm{SO}_{2}$ emissions (VOL) and DMS emissions over the 16 tagged source regions/sectors averaged for the most recent 5 years (2010-2014) and Fig. 1b presents relative contributions from individual source regions to the global combustion $\mathrm{SO}_{2}$ emissions. The global combustion $\mathrm{SO}_{2}$ emissions rate is $57.6 \mathrm{Tg} \mathrm{S} \mathrm{yr}^{-1}$, of which more than $98 \%$ comes from anthropogenic sources. The combustion $\mathrm{SO}_{2}$ and sulfate are referred to as anthropogenic $\mathrm{SO}_{2}$ and sulfate hereafter. Detailed information on the anthropogenic emissions of $\mathrm{SO}_{2}$ can be found in Hoesly et al. (2017). East Asia, with regional emissions of $17.8 \mathrm{Tg} \mathrm{S} \mathrm{yr}^{-1}$ (31\% of global anthropogenic $\mathrm{SO}_{2}$ ), has the largest total $\mathrm{SO}_{2}$ emissions, compared to the other tagged regions. South Asia also emits a large amount of $\mathrm{SO}_{2}, 6.4 \mathrm{Tg} \mathrm{S} \mathrm{yr}^{-1}(11 \%)$, followed by $3.4 \mathrm{Tg} \mathrm{S} \mathrm{yr}^{-1}(6 \%)$ from the Middle East, $3.3 \mathrm{Tg} \mathrm{S} \mathrm{yr}^{-1}$ (6\%) from Europe, $3.1 \mathrm{Tg} \mathrm{S} \mathrm{yr}^{-1}(5 \%)$ from North America and $2.7 \mathrm{Tg} \mathrm{S} \mathrm{yr}^{-1}$ (5\%) from Southern Africa. The other individual tagged regions have weaker emissions, with a combined contribution of less than $5 \%$. However, emissions from ROW contribute $11.2 \mathrm{Tg} \mathrm{S} \mathrm{yr}^{-1}(19 \%)$ of $\mathrm{SO}_{2}$ that are mainly from shipping emissions near the continents. In addition, natural emissions of sulfur are also accounted for, including $12.6 \mathrm{Tg} \mathrm{S} \mathrm{yr}^{-1}$ of $\mathrm{SO}_{2}$ from volcanic eruptions, in the range of $10-13 \mathrm{Tg} \mathrm{S} \mathrm{yr}^{-1}$ derived from the Ozone Monitoring Instrument (OMI) measurement (McLinden et al., 2016) and 18.2 $\mathrm{Tg} \mathrm{S} \mathrm{yr}^{-1}$ of DMS. Figure $\mathrm{S} 2$ shows the spatial distribution of $\mathrm{SO}_{2}$ emissions from each tagged region/sector as well as DMS emissions. Emissions are spatially heterogeneous even within the individual tagged regions. For instance, $\mathrm{SO}_{2}$ emissions in North America are mainly located in eastern US, and eastern China accounts for the majority of $\mathrm{SO}_{2}$ emissions from East Asia. In addition, seasonal variations in emissions are quite different among the source regions (Table 1). East Asia, RBU and Europe have seasonal 

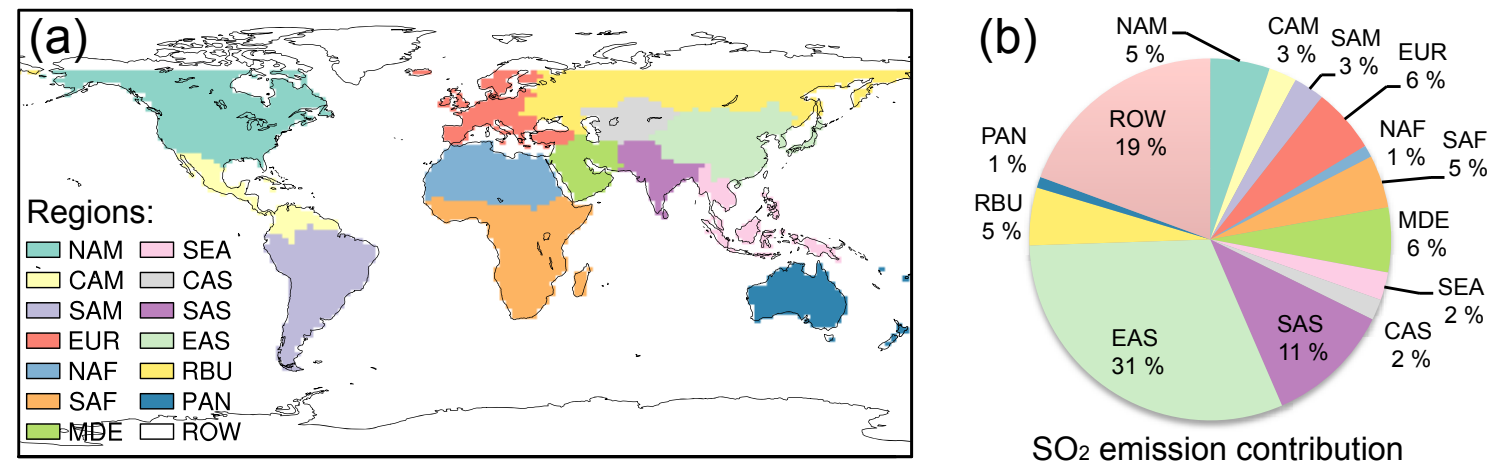

$\mathrm{SO}_{2}$ emission contribution

Figure 1. (a) Tagged source regions (NAM: North America; CAM: Central America; SAM: South America; EUR: Europe; NAF: North Africa; SAF: Southern Africa; MDE: the Middle East; SEA: Southeast Asia; CAS: Central Asia; SAS: South Asia; EAS: East Asia; RBU: Russia/Belarus/Ukraine; PAN: Pacific/Australia/New Zealand; and ROW: rest of the world) and (b) the respective percentage contributions to global annual mean combustion $\mathrm{SO}_{2}$ emissions (anthropogenic + biomass burning) from the individual source regions.

Table 1. Annual and seasonal total emissions (unit: $\mathrm{TgS}$ ) of combustion (anthropogenic + biomass burning) $\mathrm{SO}_{2}$ and DMS from the 16 source regions/sectors in December-January-February (DJF), March-April-May (MAM), June-July-August (JJA), and September-October-November (SON).

\begin{tabular}{lllllllll}
\hline & NAM & CAM & SAM & EUR & NAF & SAF & MDE & SEA \\
\hline DJF & 0.83 & 0.35 & 0.33 & 1.07 & 0.15 & 0.65 & 0.84 & 0.35 \\
MAM & 0.70 & 0.37 & 0.37 & 0.83 & 0.15 & 0.59 & 0.84 & 0.37 \\
JJA & 0.88 & 0.37 & 0.47 & 0.65 & 0.15 & 0.81 & 0.84 & 0.35 \\
SON & 0.70 & 0.36 & 0.44 & 0.78 & 0.15 & 0.66 & 0.84 & 0.35 \\
ANN & 3.11 & 1.44 & 1.61 & 3.33 & 0.61 & 2.71 & 3.36 & 1.43 \\
\hline & CAS & SAS & EAS & RBU & PAN & ROW & VOL & DMS \\
\hline DJF & 0.32 & 1.59 & 5.04 & 0.89 & 0.13 & 2.84 & 3.11 & 5.99 \\
MAM & 0.27 & 1.63 & 4.41 & 0.74 & 0.14 & 2.77 & 3.18 & 4.77 \\
JJA & 0.23 & 1.61 & 4.08 & 0.65 & 0.16 & 2.74 & 3.18 & 3.54 \\
SON & 0.26 & 1.59 & 4.30 & 0.69 & 0.16 & 2.81 & 3.14 & 3.92 \\
ANN & 1.08 & 6.42 & 17.83 & 2.98 & 0.58 & 11.16 & 12.60 & 18.22 \\
\hline
\end{tabular}

peak emissions in boreal winter due to high residential emissions from heating in this season together with higher $\mathrm{SO}_{2}$ emissions from the energy sector. Southern Africa shows larger emissions in boreal summer from biomass burning in this season, while emissions from North America are comparable in winter and summer due to the bulk of $\mathrm{SO}_{2}$ emissions arising from baseload electric power generation. DMS is emitted over oceans with a boreal winter peak due to phytoplankton blooms over the Southern Ocean. These heterogeneous spatial and temporal distributions of emissions could lead to different influences on air quality and radiative forcing over continents and subcontinents near the source regions.

\subsection{Model configurations}

The CAM5 simulation is conducted using a meteorological nudging method (Ma et al., 2013; Zhang et al., 2014), with winds nudged to the MERRA reanalysis (Rienecker et al., 2011) every $6 \mathrm{~h}$. Simulations performed are shown below:

1. Base simulation: the simulation is integrated for years 2009-2014, with 2009 for spin-up and 2010-2014 for analysis.

2. All reduction simulation: one sensitivity simulation with the same base model configuration but having a uniform $20 \%$ reduction in sulfur $\left(\mathrm{SO}_{2}\right.$, sulfate, DMS) emissions globally is performed to quantify source attributions of incremental IRF of sulfate.

3. Source reduction simulations: three sensitivity simulations with the same base model configuration but having a $20 \%$ reduction in global DMS emissions and regional sulfur emissions over North America and East Asia, respectively, are performed to validate the decomposition of global incremental IRF into contributions from source regions/sectors using the tagging method.

4. Preindustrial simulation: one sensitivity simulation with the same base model configuration but anthropogenic $\mathrm{SO}_{2}$ emissions fixed at 1850 level globally is performed to compare incremental IRF and anthropogenic IRF of sulfate.

The $20 \%$ is chosen to follow the experiment design in the framework HTAP2. All simulations are performed at $1.9^{\circ}$ latitude by $2.5^{\circ}$ longitude horizontal grids and 30 vertical layers.

\section{Model evaluation}

To evaluate the model's performance in simulating sulfate with the latest emissions from CEDS inventory, the simulated sulfur concentrations are compared with measurements from regional observation networks. These data sets include 


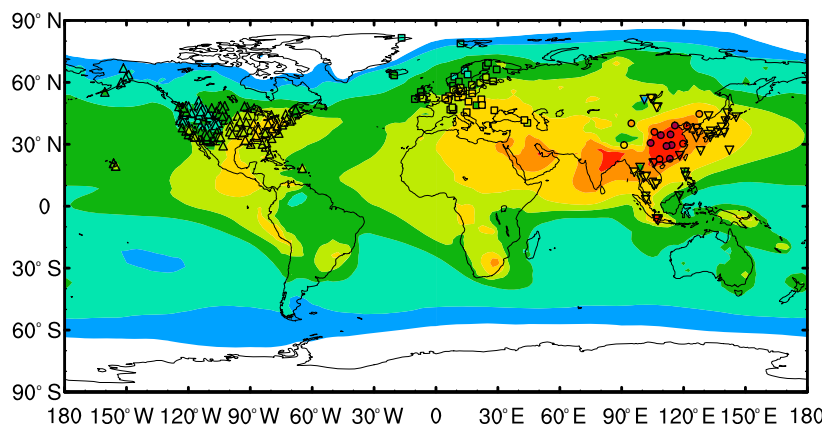

(a)
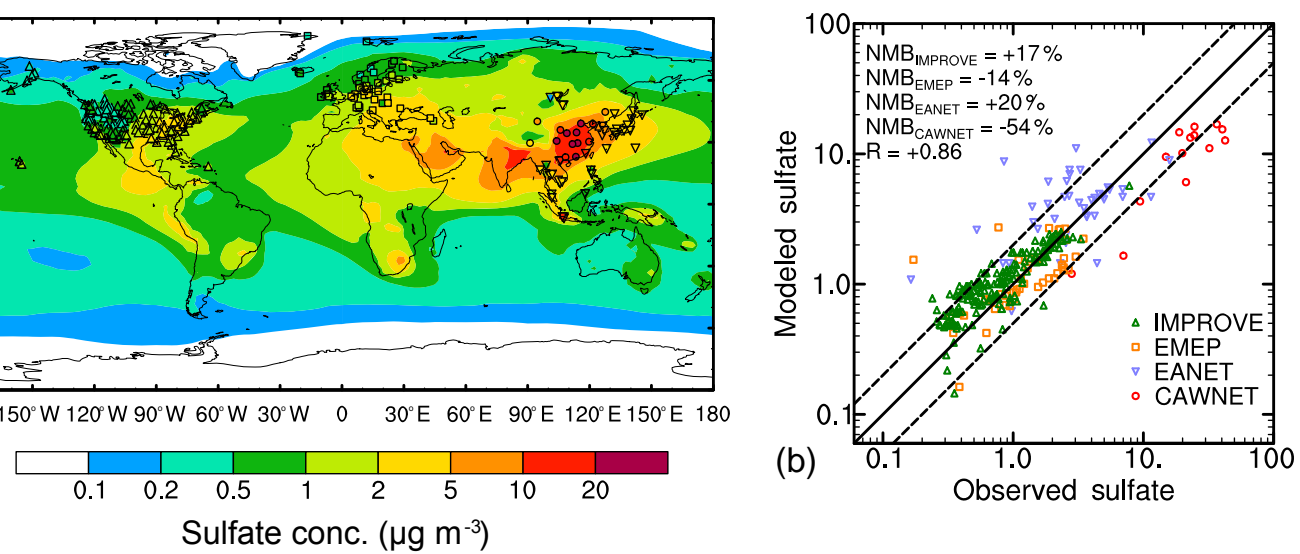

Figure 2. Spatial distribution (left panel) and scatter plot (right) between the simulated and observed annual mean near-surface sulfate concentrations $\left(\mu \mathrm{g} \mathrm{m}^{-3}\right.$ ) over years 2010-2014. Observations are from IMPROVE (upward-pointing triangle), EMEP (square), EANET (downward-pointing triangle) for years 2010-2014 and CAWNET (circle) for years 2006-2007, which are scaled to 2010-2014 based on the ratio of CEDS 2010-2014 SO 2 emissions to 2006-2007 emissions over China (0.92). Solid lines mark the $1: 1$ ratio and dashed lines mark the $1: 2$ and $2: 1$ ratios. Normalized mean bias (NMB) and correlation coefficient $(R)$ between observation and simulation are shown on the right panel. NMB $=100 \% \times \sum\left(M_{i}-O_{i}\right) / \sum O_{i}$, where $M_{i}$ and $O_{i}$ are the modeled and observed values at site $i$, respectively.

the Interagency Monitoring of Protected Visual Environments (IMPROVE), the European Monitoring and Evaluation Programme (EMEP), the East Asian Monitoring Network (EANET) and the China Meteorological Administration Atmosphere Watch Network (CAWNET; Zhang et al., 2012). Sulfate concentrations observed from IMPROVE, EMEP and EANET being used here are from 2010 to 2014, covering the same time period as the simulation, while CAWNET only collected data over 2006-2007. In order to use the CAWNET data to evaluate 2010-2014 simulation results, we decide to scale the observed sulfate mass concentrations using the ratio of CEDS 2010-2014 $\mathrm{SO}_{2}$ emissions to 2006-2007 emissions over China (0.92) for comparison, thus assuming a linear relationship between $\mathrm{SO}_{2}$ emissions and sulfate concentrations.

Figure 2 shows the comparison of modeled annual mean near-surface sulfate concentrations with those from the observational networks. The model successfully reproduces the global spatial distribution of sulfate with high concentrations over East Asia and low concentrations over North America and Europe, as well as the spatial patterns within major continents, for instance, high (low) values over eastern (western) US and high (low) sulfate concentrations over eastern (western) China. The spatial correlation coefficient between simulated and observed sulfate concentrations globally is +0.86 and is statistically significant at the 95th percentile. Compared to the measurements at the IMPROVE sites over North America, at the EMEP sites over Europe, and at the EANET sites over part of East Asia (only one site in China) and Southeast Asia, the model reproduces sulfate concentrations with biases within $\pm 20 \%$. However, the model largely underestimates the simulated sulfate concentrations in China, with normalized mean biases (NMB) of $-54 \%$, compared to the CAWNET observations.

A few factors could be responsible for the bias between the observed and modeled sulfate concentrations. Underestimation of local $\mathrm{SO}_{2}$ emissions could result in the simulated low sulfate concentrations (Liu et al., 2012; Wang et al., 2013). Too frequent liquid clouds and too strong wet scavenging at the mid- and high latitudes in CESM model can lead to shorter aerosol lifetime and lower concentrations in the simulation (M. Wang et al., 2011; Liu et al., 2012; H. Wang et al., 2013). In addition, the underestimation of emissions from upwind regions or strong wet scavenging of aerosols during transport could be another reason for the simulated low bias (Yang et al., 2017). Too low a rate of transformation from $\mathrm{SO}_{2}$ gas to sulfate particles in the model could also contribute to the low bias in sulfate concentrations (Wang et al., 2016; $\mathrm{Li}$ et al., 2017). The bias can also result from the fact that the site measurements are point observations, while the model results are grid-cell average that does not consider subgrid aerosol variations (Qian et al., 2010; R. Wang et al., 2014). In addition, different models show large discrepancies in simulating sulfate over China (Kasoar et al., 2016). The underestimation of sulfate in China can lead to an underestimation of source contribution from East Asia of sulfate concentrations, direct and indirect radiative forcing of sulfate and forcing efficiencies of sulfate.

To evaluate the model results more broadly, we compare the simulated total column burden of $\mathrm{SO}_{2}$ with that derived from the OMI measurements ( $\mathrm{Li}$ et al., 2013), as shown in Fig. S3. Both the model results and the OMI satellite data are averaged over 2010-2014. Compared to the OMI $\mathrm{SO}_{2}$, the spatial distribution of column burden of $\mathrm{SO}_{2}$ is reproduced in CAM5, with a statistically significant spatial correlation co- 
efficient of +0.57 . However, the model largely overestimates the magnitude of $\mathrm{SO}_{2}$, especially over China where the simulated values are about 8 times larger than OMI data. Outside of China, simulated $\mathrm{SO}_{2}$ burdens are 3-7 times larger than OMI data over North America, Europe and Southeast Asia. The large difference between $\mathrm{SO}_{2}$ burden and OMI retrievals must be due to either an underestimation of $\mathrm{SO}_{2}$ in OMI products and/or an overestimation of $\mathrm{SO}_{2}$ burden in the model results. He et al. (2012) compared in situ measurements with $\mathrm{OMI} \mathrm{SO}_{2}$ burden over central China and reported a negative bias of $50 \%$ in OMI data, which probably came from cloud contamination, reduced satellite sensitivity to $\mathrm{SO}_{2}$ due to aerosols and spatial sampling bias in the satellite data. It is also worth mentioning that satellite column$\mathrm{SO}_{2}$ retrievals depend on the vertical distribution of $\mathrm{SO}_{2}$ assumed in the retrieval algorithm, which could be different from either the modeled $\mathrm{SO}_{2}$ profile in this study or the actual profile, which would introduce a bias.

The simulated near-surface $\mathrm{SO}_{2}$ concentrations, however, are also underestimated by $25 \%$ compared to observations over 13 sites in China (Gong et al., 2014) shown in Fig. S4a, also suggesting a large bias in satellite retrievals or too much $\mathrm{SO}_{2}$ simulated at higher altitudes. In general, transport is more efficient in the free troposphere. If too much $\mathrm{SO}_{2}$ is simulated at higher altitudes, the near-surface $\mathrm{SO}_{2}$ concentrations are likely to be overestimated over downwind regions. However, the modeled $\mathrm{SO}_{2}$ concentrations over downwind regions of China are underestimated by $45 \%$ compared to observations from EANET sites (Fig. S4b). This indicates that bias in the satellite retrievals may be a significant cause of the inconsistency between modeled and satellite-estimated $\mathrm{SO}_{2}$ burden.

Less efficient transformation of $\mathrm{SO}_{2}$ to sulfate could also lead to underestimation of sulfate. A recent study by Wang et al. (2016) focusing on the sulfate pollution over China and London found that aqueous oxidation of $\mathrm{SO}_{2}$ by $\mathrm{NO}_{2}$ was key to efficient sulfate formation, which has typically been neglected in atmospheric models and is not considered in the CAM5. Another study by $\mathrm{Li}$ et al. (2017) found that including an aerosol water $\left(\mathrm{HRSO}_{2}\right)$ parameterization in $\mathrm{SO}_{2}$ oxidation in a box model could reproduce the observed rapid sulfate formation in Xi' an over China. More rapid oxidation of $\mathrm{SO}_{2}$ would reduce $\mathrm{SO}_{2}$ loss by dry and wet removal and increase sulfate production, which can partly explain the low bias in the simulated sulfate concentrations and high bias in $\mathrm{SO}_{2}$. In CAM5, $36 \%$ of total sulfur converts into columnintegrated sulfate over China, similar to $33 \%$ in the Community Multiscale Air Quality (CMAQ) model (He et al., 2012). However, it changes to $21 \%$ in the bottom model layer (about $992 \mathrm{hPa}$ ), indicating that the oxidation of $\mathrm{SO}_{2}$ may be underestimated near the surface, which most directly affects the comparison to near-surface observations. This appears to be a plausible explanation for the underestimated sulfate concentrations over China and points to a potentially important direction for future model development.
Biases in simulated precipitation can also lead to biases in sulfate concentrations. Figure S5 compares annual mean precipitation from CMAP (Climate Prediction Center's Merged Analysis of Precipitation) and that simulated in this study. Over China, CAM5 overestimates precipitation over northern China, which leads to strong aerosol scavenging and low sulfate concentrations over this region.

\section{Source attribution of sulfate mass concentrations}

Figure 3 shows spatial distributions of modeled fractional contributions to annual near-surface sulfate concentrations. (The absolute concentrations of sulfate are shown in Fig. S6). East Asia, ROW, South Asia and the Middle East contribute $16,14,10$ and $7 \%$, respectively, to global annual mean nearsurface sulfate concentrations, whereas contributions from the other individual source regions are all less than $5 \%$. Natural emissions of volcanic $\mathrm{SO}_{2}$ and ocean DMS account for 11 and $16 \%$ of global mean sulfate concentrations. Sulfate concentrations are mostly contributed by local sources in regions with high emissions, such as eastern US, Southern Africa, South Asia and eastern China, where local source contributions are larger than $80 \%$. Over regions with relatively low $\mathrm{SO}_{2}$ emissions, the near-surface sulfate concentrations are primarily attributed to non-local sources from long-range transport. Natural DMS emissions are the source of $80 \%$ of near-surface sulfate concentrations over Southern Hemisphere oceans and 20-60\% for Northern Hemisphere oceans. Over downwind ocean regions of East Asia, emissions from DMS only account for $20-40 \%$ of nearsurface sulfate concentrations, showing stronger influence of regional transport. Sources from volcanic eruption strongly influence sulfate concentrations over eruption regions. They are responsible for $10-40 \%$ of near-surface concentrations over Central America and South America, 40-80\% over North Africa and Southeast Asia but only account for about less than $5 \%$ over East and South Asia, where anthropogenic emissions dominate.

The spatial distribution of sulfate column burden and relative contributions are shown in Figs. S7 and S8, respectively. The global average source attribution of column burden does not differ significantly from that of near-surface concentrations. The exception is an increase from 11 to $15 \%$ of the relative contribution from VOL to column burden as compared to near-surface concentrations due to injection mostly into the free troposphere. The DMS contribution decreases from 16 to $11 \%$ to compensate for the increase of the VOL contribution over oceans. In general, the relative contribution from local source to column burden within a source region is lower than that of near-surface concentrations.

Figure 4 presents relative contributions of major sources to near-surface sulfate concentrations in neighboring receptor regions along with seasonal mean wind fields at $850 \mathrm{hPa}$. (Supplement Table S1 summarizes a complete list of num- 

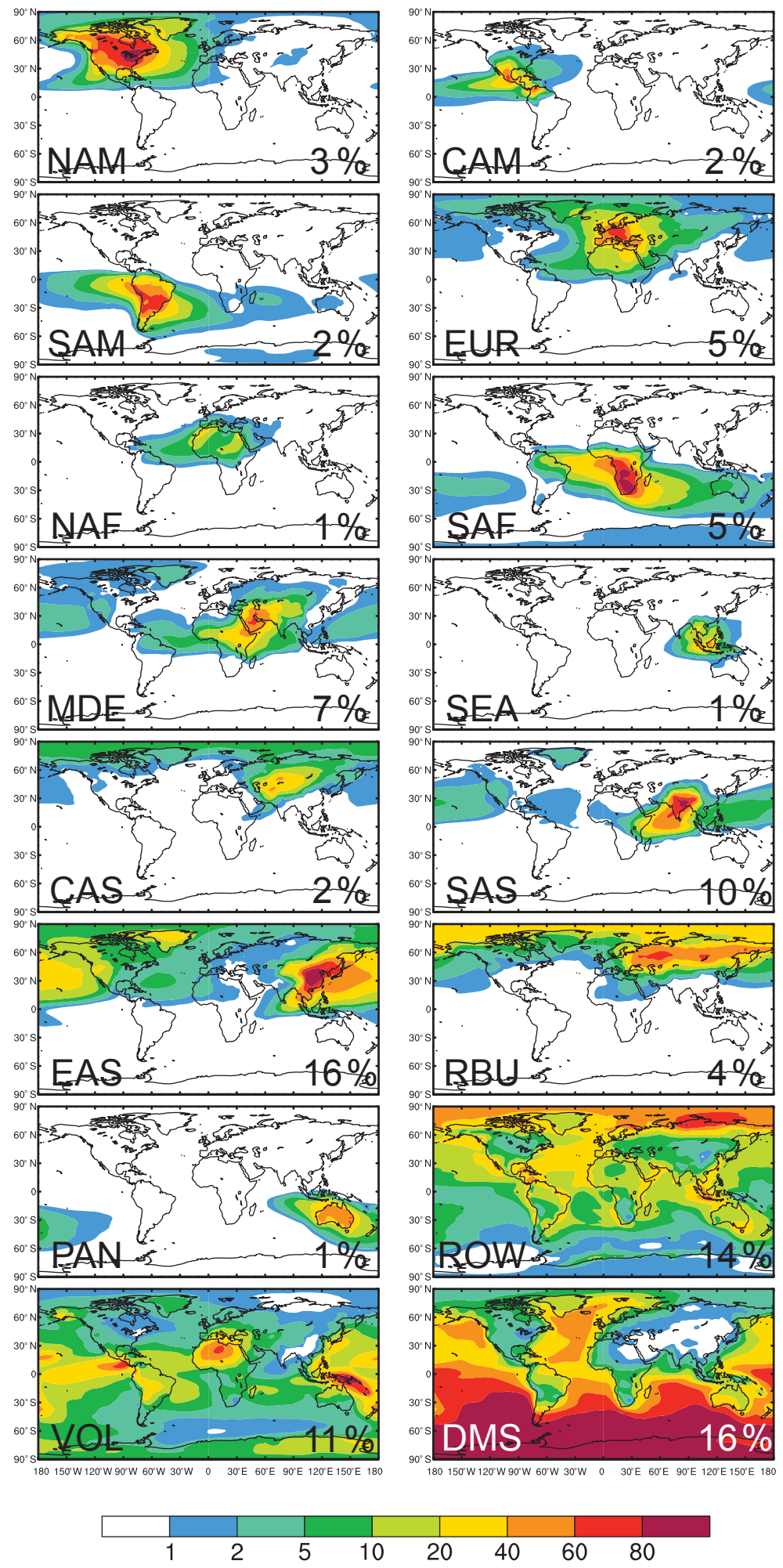

Relative contribution to sulfate conc. (\%)

Figure 3. Spatial distribution of relative contributions (\%) to annual mean near-surface sulfate concentrations from each of the tagged source regions/sectors. Relative contributions to global averaged sulfate from individual source regions/sectors is shown at the bottom right of each panel. 
(a) Non-local source contribution (\%)
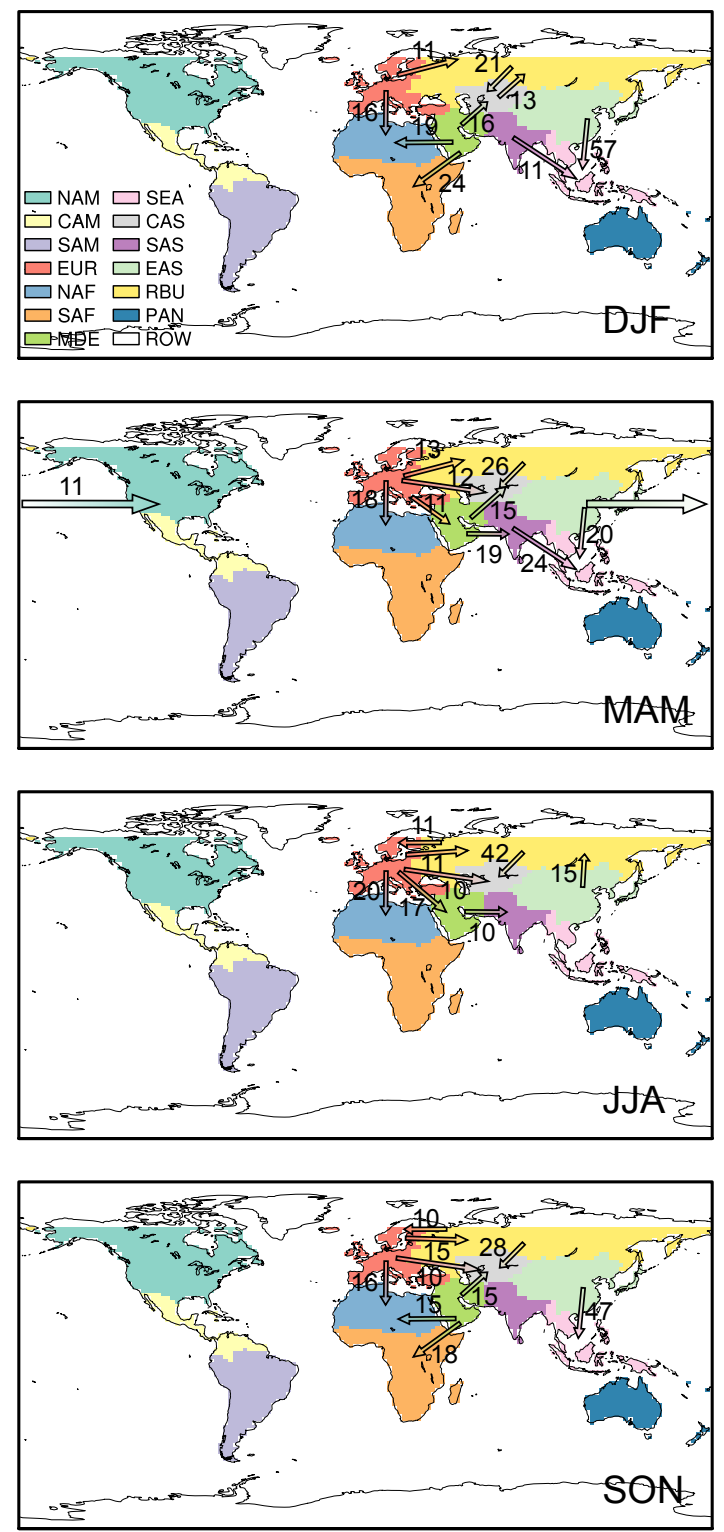

(b) Winds over $850 \mathrm{hPa}\left(\mathrm{m} \mathrm{s}^{-1}\right)$
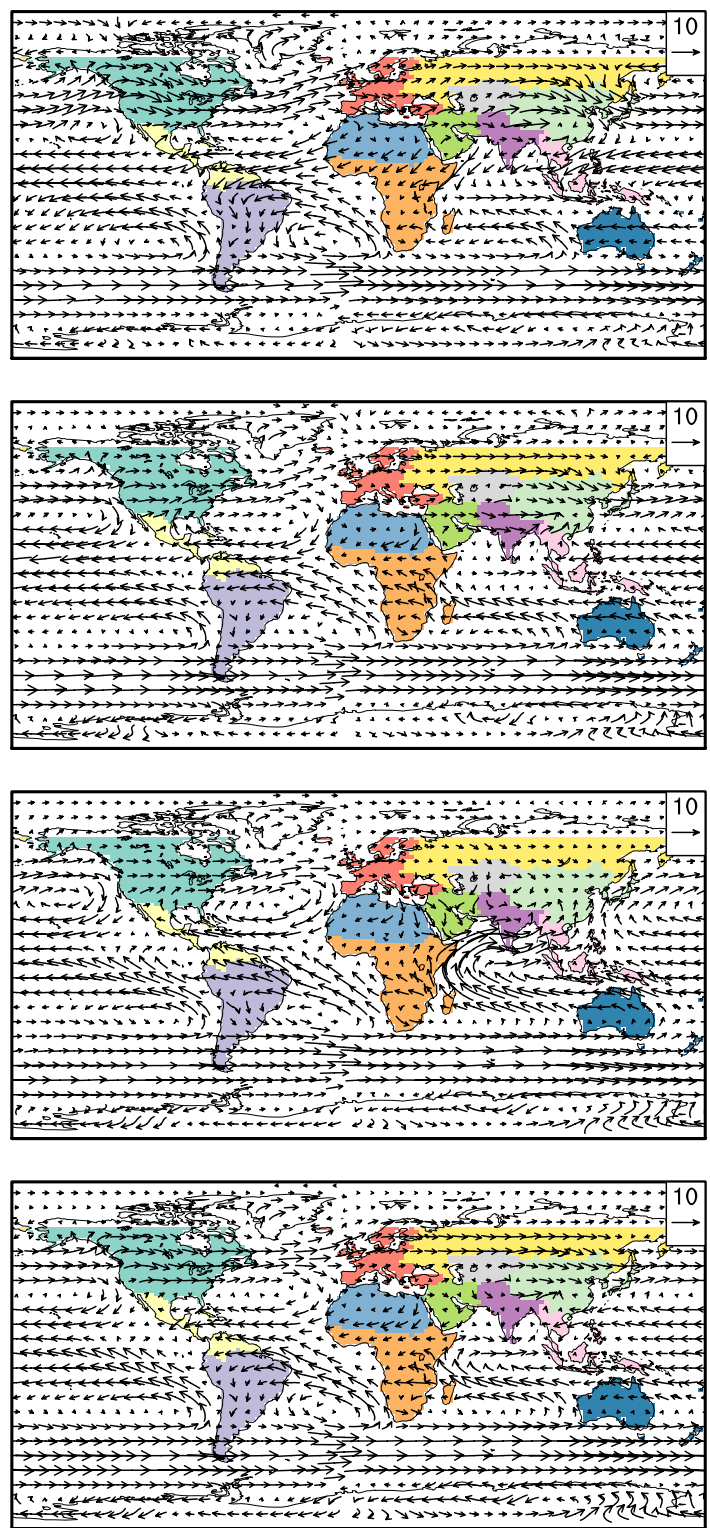

Figure 4. Relative contributions of non-local sources to seasonal near-surface sulfate concentrations (left panels) and wind fields over $850 \mathrm{hPa}$ (right panels). Arrows with numbers show contributions (\%) of a source region to sulfate over a receptor region. Only relative concentrations larger than $10 \%$ are shown.

bers characterizing the source-receptor relationships.) Transport of sulfate shows different patterns in different seasons, due to the seasonal variability in local precursor emissions, lifetime of sulfate and meteorology, such as wind fields and precipitation.

The export of sulfate from Europe contributes to about 16-20\% of near-surface sulfate concentrations over North Africa, RBU and Central Asia in all seasons due to the westerly jet over the eastern European boundary and northerly winds over southern boundary. Sulfate from the Middle East can be effectively transported to the surrounding receptor regions. This export accounts for 15-24\% of sulfate concentrations over North Africa, Southern Africa and Central Asia in DJF and SON, and $19 \%$ over South Asia in MAM. Sources in the RBU explain about $21-42 \%$ of sulfate concentrations over Central Asia, especially in JJA, with northerly winds over north boundary of Central Asia driving transport from this region. Central Asia accounts for $13 \%$ of sulfate over the RBU region in DJF, when source emissions are the largest. Northerly winds over East Asia in DJF and SON associated 

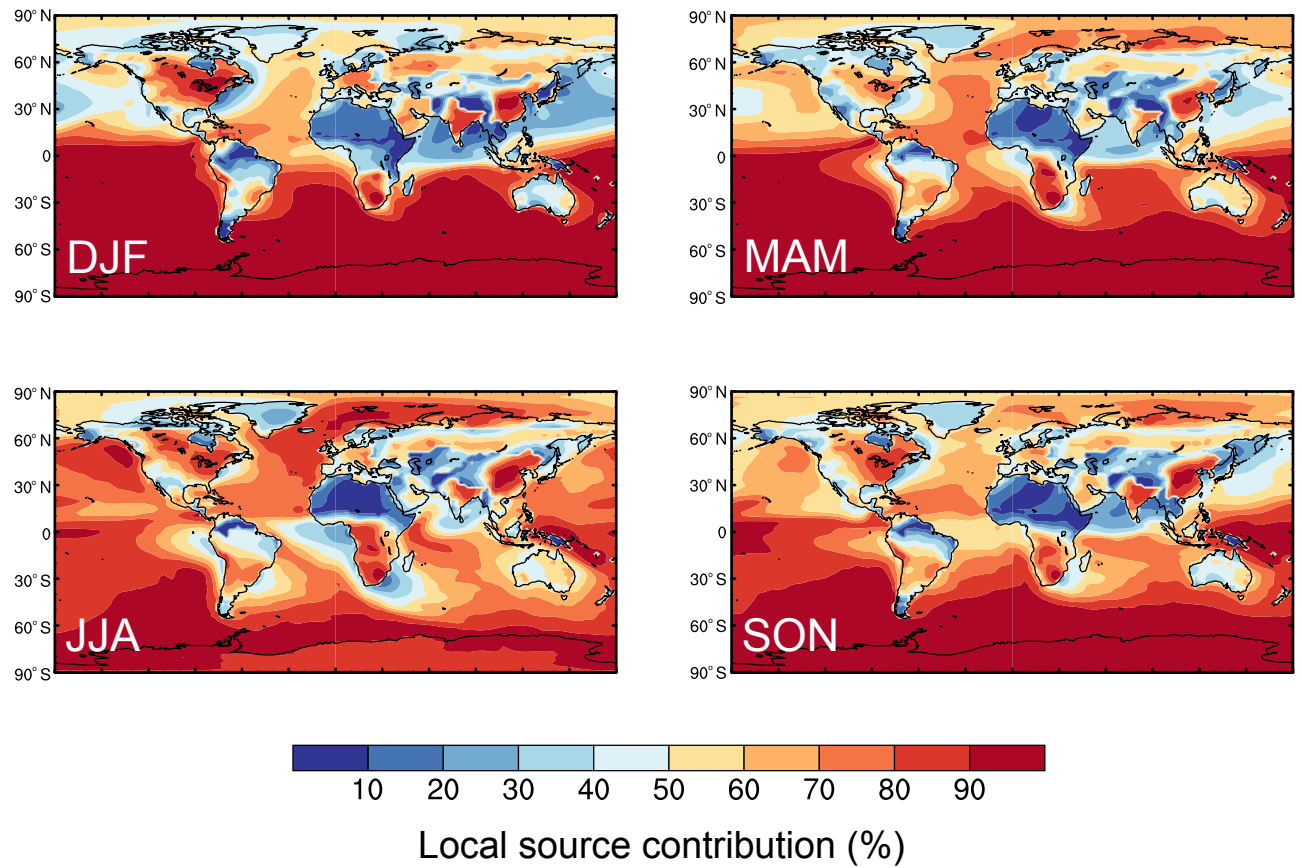

Figure 5. Relative contributions (\%) of local emissions (inside the tagged regions) to near-surface sulfate concentrations. Contributions from natural source sectors are added to ROW here. Contributions less than $50 \%$ are shown in cold colors and those larger than $50 \%$ are shown in warm colors.

with the East Asian winter monsoon transport sulfate from highly polluted eastern China to Southeast Asia, which accounts for about $50 \%$ of near-surface sulfate concentrations over Southeast Asia in these months. The oxidation of $\mathrm{SO}_{2}$ is expected to peak in JJA because of the high temperature and humidity as well as more sunlight. With the help of southerly winds of East Asian summer monsoon, East Asia contributes to $15 \%$ of sulfate concentrations over RBU in JJA. Due to the strong westerly jet in MAM, sulfate originating from East Asia has a long-range transport across the North Pacific and accounts for $11 \%$ of near-surface sulfate concentrations and $25 \%$ of total imported sulfate (without local contributions) over North America. The transport of sulfate from South Asia contributes 11-24\% of sulfate in Southeast Asia in DJF and MAM. These results, however, have additional uncertainties due to the $\mathrm{SO}_{2}$ /sulfate bias in the model for East Asia discussed previously.

Source-receptor relationships for sulfate column burden are summarized in Table S2. Compared to the near-surface concentrations, the sulfate column burden contributed by local sources is much lower in all the receptor regions due to the more efficient long-range transport of aerosols in the free atmosphere. Annually, the local contribution over North America decreases from $67 \%$ for near-surface concentrations to $33 \%$ for column burden. The contributions of nonlocal sources from East and South Asia increase from 7 and $1 \%$ for near-surface concentrations to 24 and $10 \%$ for column burden, respectively, to the sulfate over North Amer- ica. In addition, the South Asia contribution to sulfate in East Asia, and East Asia contribution to sulfate in RBU and Europe also significantly increase for column burden compared to near-surface concentrations.

Figure 5 shows local contributions (i.e., from sources within the tagged regions) to near-surface sulfate concentrations. Averaged over individual tagged regions, contributions from local sources dominate (i.e., local contributions $>50 \%$ ) over North America, South America, Europe, Southern Africa, the Middle East, South Asia and East Asia. Imports dominate near-surface sulfate concentrations (i.e., local contributions $<50 \%$ ) over the rest of tagged land regions. Within each tagged region, whether local source or import dominates depends on specific locations. For instance, over eastern China, because of high anthropogenic emissions, the local contribution to sulfate concentrations is larger than $80 \%$, whereas import from other source regions dominates sulfate over the less economically developed western China. The same difference can be found between eastern and western US of the tagged North America. Over oceans in the Southern Hemisphere, natural sources of DMS contribute the largest to local sulfate concentrations (Fig. 3), whereas longrange transport dominates over the North Pacific in DJF and MAM.

Figure 6 presents the aggregate, seasonal relative source contributions to area-weighted average near-surface sulfate concentrations over land/ocean in the Northern and Southern hemispheres. Over land in the Northern Hemisphere, sul- 

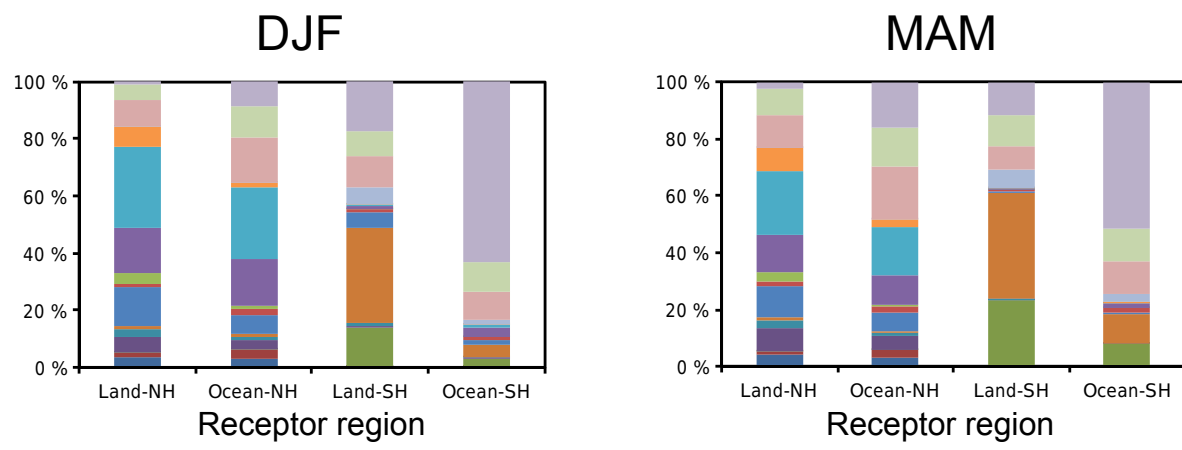

Sources:
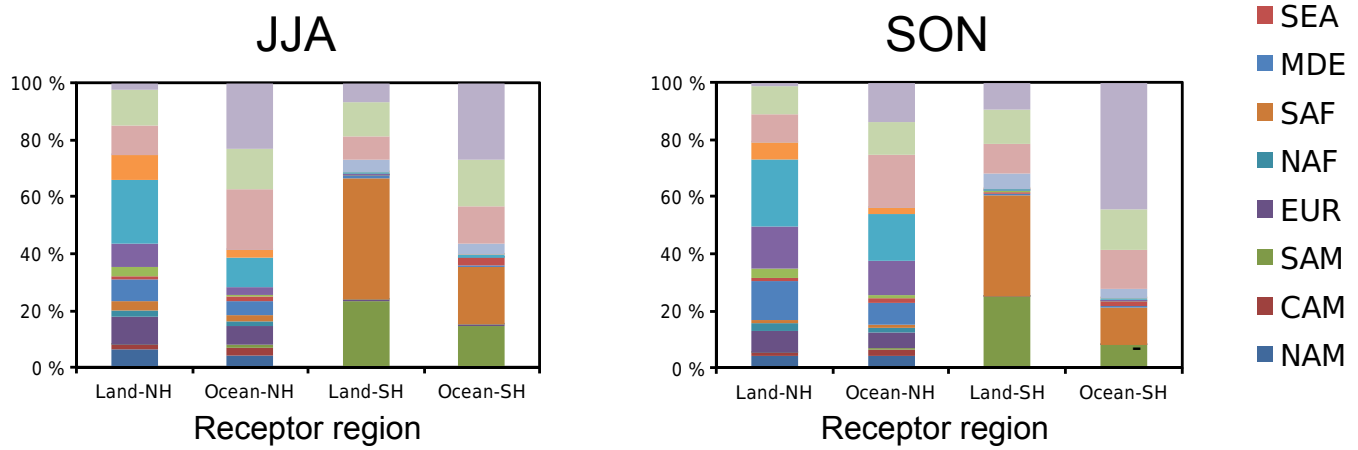

Figure 6. Relative contributions $(\%)$ to near-surface sulfate concentrations averaged over land and ocean of the Northern and Southern hemispheres from emissions in the 16 tagged source regions/sectors.

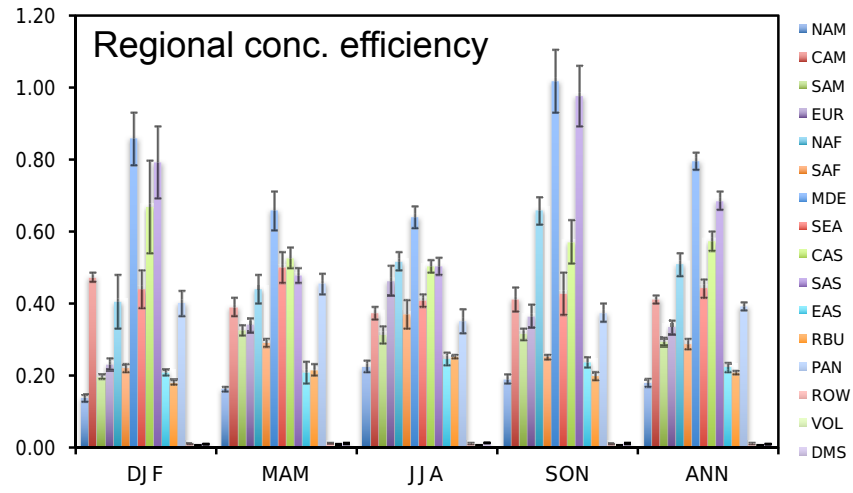

Figure 7. Seasonal and annual mean regional concentration efficiency of sulfate $\left(\mu \mathrm{g} \mathrm{m}^{-3}\left(\mathrm{Tg} \mathrm{S} \mathrm{yr}^{-1}\right)^{-1}\right)$ of the 16 tagged source regions/sectors. The efficiency is defined as the local contribution to near-surface sulfate concentrations divided by the corresponding sulfur emissions from that region (seasonal emissions multiplied by 4 ). Error bars indicate $1 \sigma$ of mean values during years 2010 2014. The receptor region of ROW is used to calculate efficiency of VOL and DMS.

fate concentrations are mainly attributed to sources from East Asia, South Asia, the Middle East, ROW and volcanic eruption, with relative contributions of 22-29, 9-16, 8-14, 9-11 and $6-13 \%$, respectively. Over ocean in the Northern Hemisphere, although the contribution from ROW, volcanic $\mathrm{SO}_{2}$ and DMS increase dramatically compared to land, contribu- tions from East and South Asia do not have a large decrease, especially in DJF, MAM and SON, when aerosol outflow from Asia is strong (Yu et al., 2012, 2015). Over land in the Southern Hemisphere, mean sulfate concentrations are dominated by sources from Southern Africa, having a contribution of 33-43\%, followed by 13-25\% from South America. Emissions from DMS drive sulfate over ocean in the Southern Hemisphere in all seasons contributing $27-63 \%$ of sulfate, although Southern Africa contributes $20 \%$ of sulfate in JJA.

Figure 7 shows seasonal and annual mean regional concentration efficiencies of sulfate from the tagged source regions/sectors, defined as the local contribution to nearsurface sulfate concentrations divided by the corresponding sulfur emissions from that region. (Table $\mathrm{S} 3$ provides the numeric values.) The regional concentration efficiency represents the relationship between the local contribution to sulfate concentrations and local emissions, which is influenced by many factors, such as local production of sulfate from the emitted $\mathrm{SO}_{2}$, aerosol removal and export. Note that the receptor region of ROW is used to calculate efficiencies of the VOL and DMS source sectors, which leads to low biases in efficiencies. The efficiencies over the Middle East show high values in almost all seasons due to dry atmospheric conditions favoring long aerosol lifetime, especially in DJF and SON (e.g., Wang et al., 2014; Stjern et al., 2016). The efficiencies are also high over South Asia in DJF and SON, but low in MAM and JJA due to strong wet removal during 
the South Asian summer monsoon season. North Africa and Central Asia also show high efficiencies resulted from less precipitation. Although East Asia does not have much precipitation in DJF, the efficiency is low because a large amount of sulfate is transported outside East Asia. It suggests that the lifetime of aerosols, mainly driven by wet deposition, together with regional export, is important in determining the local contribution to near-surface concentrations or regional air quality.

\section{Source attribution of direct and indirect radiative forcing of sulfate}

The modeled global annual mean sulfate total DRF here is $-0.42 \mathrm{~W} \mathrm{~m}^{-2}$, with $-0.31 \mathrm{~W} \mathrm{~m}^{-2}$ contributed by anthropogenic sulfate and $-0.11 \mathrm{~W} \mathrm{~m}^{-2}$ contributed by natural sulfate (e.g., relative to a state with no natural emissions). The DRF of anthropogenic sulfate is $-0.4 \pm 0.2 \mathrm{~W} \mathrm{~m}^{-2}$ provided in the Fifth Assessment Report of the Intergovernmental Panel on Climate Change (IPCC, 2013). Note that the DRF of anthropogenic sulfate calculated here is total anthropogenic sulfate, whereas values from IPCC represent changes in anthropogenic sulfate between 1750 and present-day conditions, although this difference is small since $1750 \mathrm{SO}_{2}$ emissions are less than $1 \%$ of 2010 emissions. Spatial distributions of sulfate DRF, originating from the individual 16 sources, are shown in Fig. S9. The spatial distributions and global contributions of sulfate DRF are similar to those of sulfate column burden (Fig. S7), except that the contribution of DMS to global sulfate DRF (18\%) is much larger relative to its global column burden (11\%). It is because DMSproduced sulfate burden is mostly located between $30^{\circ} \mathrm{S}$ and $30^{\circ} \mathrm{N}$ (Fig. S7), where insolation is much stronger than at mid- and high latitudes, leading to stronger DRF over these regions. East Asia is the second-largest contributor to global sulfate DRF, contributing $16 \%$ of global sulfate DRF, followed by $13 \%$ from ROW and $11 \%$ from South Asia.

Figure 8 shows seasonal and zonal mean DRF of sulfate originating from the tagged regions/sectors and the global total. The meridional distribution of DRF is jointly determined by many factors, e.g., sulfate loading, the insolation, cloud cover and surface albedo. The total sulfate DRF shows a seasonal pattern that has the maximum DRF over $0-10^{\circ} \mathrm{N}$ in DJF and over $30-40^{\circ} \mathrm{N}$ in JJA, with values between -0.9 and $-1.3 \mathrm{~W} \mathrm{~m}^{-2}$. The global and annual average sulfate DRF has a contribution of $-0.074 \mathrm{~W} \mathrm{~m}^{-2}$ from DMS, $-0.068 \mathrm{~W} \mathrm{~m}^{-2}$ from East Asia, $-0.054 \mathrm{~W} \mathrm{~m}^{-2}$ from ROW, $-0.047 \mathrm{~W} \mathrm{~m}^{-2}$ from South Asia, $-0.035 \mathrm{~W} \mathrm{~m}^{-2}$ from VOL, $-0.031 \mathrm{~W} \mathrm{~m}^{-2}$ from the Middle East, $-0.023 \mathrm{~W} \mathrm{~m}^{-2}$ from Southern Africa, $-0.018 \mathrm{~W} \mathrm{~m}^{-2}$ from Europe, $-0.016 \mathrm{~W} \mathrm{~m}^{-2}$ from North America, and a total of $-0.057 \mathrm{~W} \mathrm{~m}^{-2}$ from all other regions (Table S4).

Figure 9 shows seasonal fractional contributions to sulfate DRF in different latitudinal bands. Over the Southern Hemi- sphere tropics $\left(30^{\circ} \mathrm{S}\right.$ to Equator) and mid- $\left(60-30^{\circ} \mathrm{S}\right)$ and high $\left(90-60^{\circ} \mathrm{S}\right)$ latitudes, DMS has the largest contribution to sulfate DRF in all seasons, with a contribution of about 17-84\%. Sources from Southern Africa contribute about 11$20 \%$ of sulfate DRF over the Southern Hemisphere tropic and mid-latitudes, followed by about $10 \%$ from South America and ROW. Sources from East Asia account for 6-19\% of sulfate DRF over the Southern Hemisphere high latitudes. In the Northern Hemisphere, influence from DMS becomes much weaker, but still substantial. Over the Northern Hemisphere tropics, East Asia, South Asia, ROW and DMS exert equal contributions of 10-20\%. East Asia has the largest contribution of 20-30\% over the Northern Hemisphere midand high latitudes, followed by South Asia and ROW.

Sulfate incremental IRF is estimated by using an additional simulation in which sulfur emissions are reduced by $20 \%$ for all regions and sectors. The difference in cloud radiative forcing between the control simulation and this second simulation gives the sulfate incremental IRF of the last $20 \%$ of sulfur emissions. Regional incremental IRF contributions are calculated by scaling the total incremental IRF in a grid column by regional source contributions to sulfate mass concentration reduction averaged from the surface layer to $850 \mathrm{hPa}$, which is the approximate altitude of cloud base.

Figure 10 shows regional contributions to sulfate incremental IRF from the tagged source regions/sectors. The sulfate incremental IRF is $-0.44 \mathrm{~W} \mathrm{~m}^{-2}$. The spatial pattern is consistent with that of stratiform clouds since the model only considers aerosol effects on stratiform cloud. The strong negative forcing is mainly over oceans. All source contributions to sulfate incremental IRF from the 14 tagged source regions are less than $-0.04 \mathrm{~W} \mathrm{~m}^{-2}$, probably due to the polluted conditions over or near land. Particles originating from North America, South America, Southern Africa and East Asia are also transported to ocean regions, leading to strong negative forcing there. DMS has the largest contribution, explaining $-0.23 \mathrm{~W} \mathrm{~m}^{-2}$ of the global sulfate incremental IRF, because complex cloud adjustments are likely to respond sensitively to small changes in aerosol under clean conditions (Rosenfeld et al., 2014), followed by $-0.06 \mathrm{~W} \mathrm{~m}^{-2}$ from volcanic emissions. Note that the regional contribution to incremental IRF is simply calculated by decomposing the total incremental IRF with mass concentrations based on two simulations without and with the reduction in emissions. This assumption could introduce biases considering the nonlinear relationship between mass concentrations and IRF of sulfate.

To evaluate this new method for decomposing incremental IRF into different source regions/sector contributions, the IRF for two regions (North America and East Asia) and one sector (DMS) were calculated in a traditional manner using three additional simulations in which $\mathrm{SO}_{2}$ emissions from North America, East Asia and DMS emissions were reduced by $20 \%$, respectively. The incremental IRF calculated with the two methods are compared in Fig. S10. Although the incremental IRF outside the source regions obtained from 

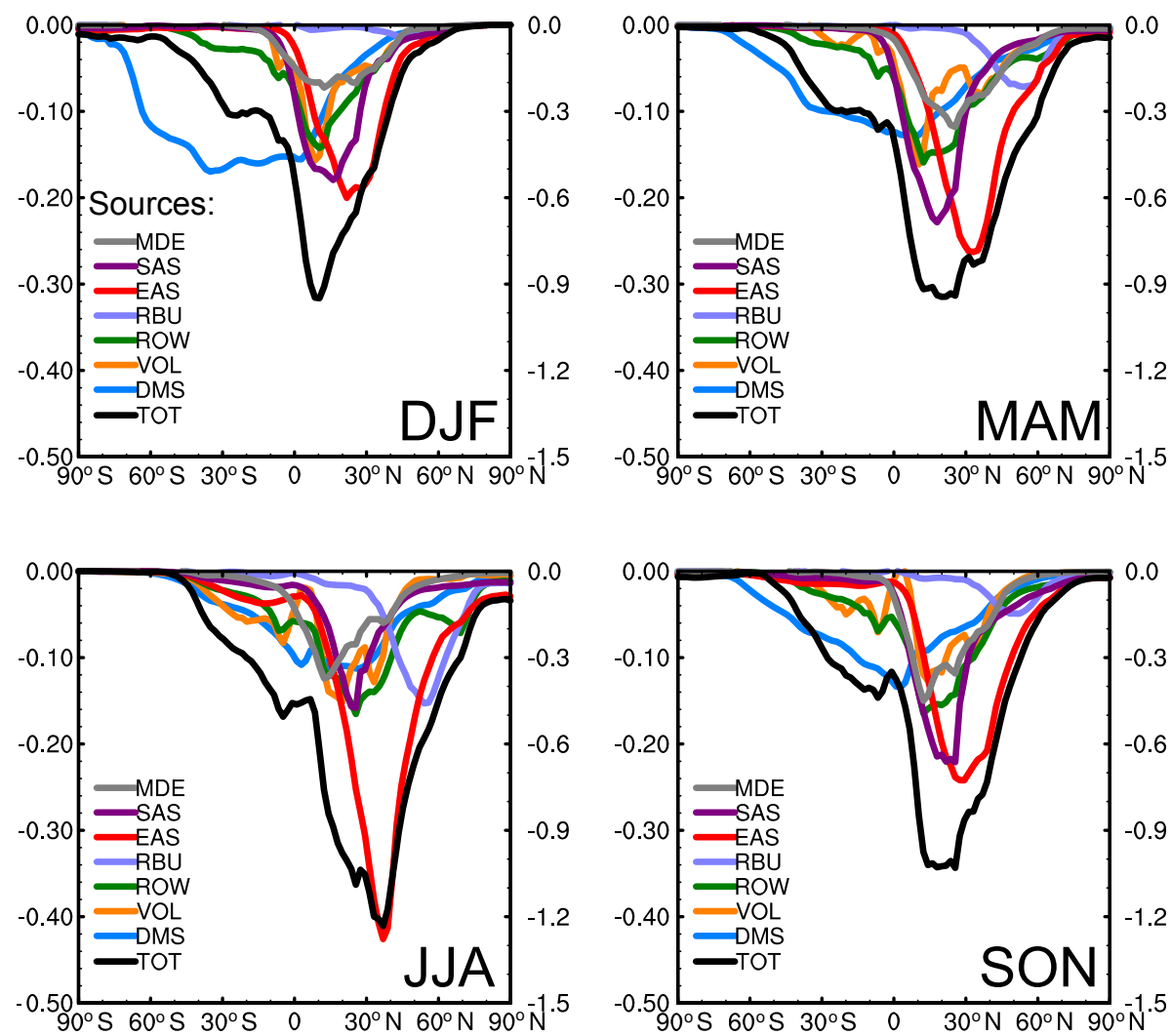

Figure 8. Contributions to zonal mean sulfate direct radiative forcing $\left(\mathrm{W} \mathrm{m}^{-2}\right)$ from emissions of the tagged regions/sectors shown in colors (left $y$ axis) and from global total emissions shown in black (right $y$ axis). Only regions with maximum of zonal mean sulfate direct radiative forcing stronger than $-0.1 \mathrm{~W} \mathrm{~m}^{-2}$ are shown here.

the emission perturbation method is noisy, these two methods show similar negative incremental IRF within and near source regions. The $20 \%$ DMS leads to strong negative IRF over oceans. The $20 \%$ of emissions from North America results in negative IRF over eastern US and downwind ocean regions. The $20 \%$ of emissions from East Asia produces negative IRF over the northwestern Pacific. Globally, DMS, North America and East Asia contribute to -0.230 $( \pm 0.012),-0.014( \pm 0.002)$ and $-0.028( \pm 0.003) \mathrm{W} \mathrm{m}^{-2}$, respectively, of sulfate incremental IRF from the method with sulfur source-tagging technique, similar to -0.248 $( \pm 0.020),-0.018( \pm 0.019)$ and $-0.028( \pm 0.018) \mathrm{W} \mathrm{m}^{-2}$, from the individual emission-perturbed simulations. The latter method has larger noise, seen in both the spatial distributions and large uncertainties (standard deviation) of the incremental IRF. The three emission-perturbed simulations produced similar system noise, with a magnitude of $\sim 0.02 \mathrm{~W} \mathrm{~m}^{-2}$. The incremental IRF signal is larger than the noise around the source regions whereas noise masks the signal in other regions, leading to large uncertainties. However, in the simulation with all source emissions reduced by $20 \%$, the IRF signal overwhelms noise almost everywhere. With the sulfur source-tagging technique and decomposition method, the noise is also decomposed into smaller pieces which are, in turn, much smaller than the decomposed incremental IRF signal.

Table S5 summarizes the DRF and incremental IRF of sulfate over land/ocean in the Northern and Southern hemispheres contributed by the tagged source regions/sectors. Over the 14 tagged source regions, the total anthropogenic source region contribution to DRF is $-0.54 /-0.18 \mathrm{~W} \mathrm{~m}^{-2}$ over land in the Northern/Southern hemispheres, larger than $-0.48 /-0.12 \mathrm{~W} \mathrm{~m}^{-2}$ over ocean due to the larger sulfate burden near sources. Anthropogenic source contributions to incremental IRF are larger over ocean, with values of $-0.23 /-0.13 \mathrm{~W} \mathrm{~m}^{-2}$ compared to $-0.08 /-0.10 \mathrm{~W} \mathrm{~m}^{-2}$ over land in the Northern/Southern hemispheres, because clouds are more susceptible to aerosol changes in clean environments and there are more stratiform clouds over ocean. For natural source sectors, their contributions are larger over oceans for both DRF and incremental IRF. Over land in the Northern Hemisphere, DRF is mainly driven by emissions from East Asia, South Asia and the Middle East, whereas incremental IRF is dominated by emissions from North America, RBU and East Asia. The difference in major contributing regions for DRF vs. incremental IRF may be due to changes in cloud susceptibility when background aerosol concentrations are different. North America and RBU have more rela- 

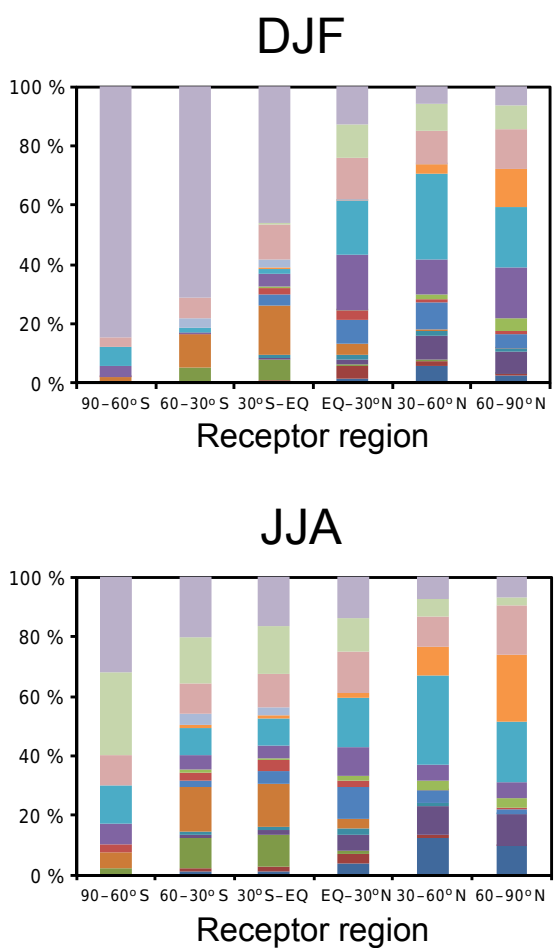

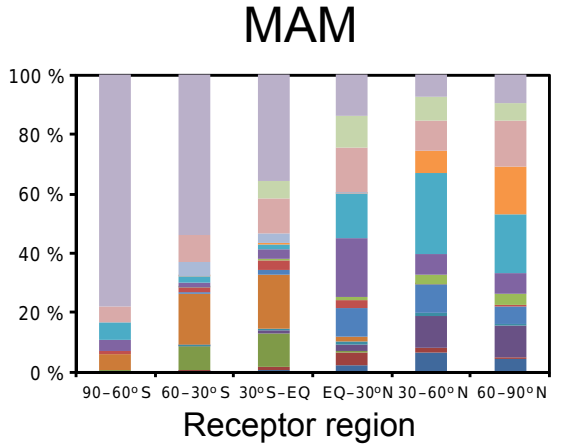

Sources:

DMS

VOL

$\square$ ROW

PAN

RBU

$\square$ EAS

- SAS

CAS

- SEA

- MDE

SAF

NAF

- EUR

SAM

- CAM

- NAM

Figure 9. Relative contributions (\%) from emissions in the 16 tagged regions/sectors to sulfate direct radiative forcing over the Southern Hemisphere high latitudes $\left(90-60^{\circ} \mathrm{S}\right)$, Southern Hemisphere mid-latitudes $\left(60-30^{\circ} \mathrm{S}\right)$, Southern Hemisphere tropics $\left(30^{\circ} \mathrm{S}\right.$ to Equator), Northern Hemisphere tropics (Equator to $\left.30^{\circ} \mathrm{N}\right)$, Northern Hemisphere mid-latitudes $\left(30-60^{\circ} \mathrm{N}\right)$ and Northern Hemisphere high latitudes $\left(60-90^{\circ} \mathrm{N}\right)$.

tively clean areas (Alaska, N. Canada, parts of Siberia) than South Asia and East Asia, and clouds in the cleaner areas are more susceptible to the $20 \%$ emissions reductions. The nonlinearity in DRF is much weaker, so the high emissions from South Asia and East Asia dominate DRF. Over ocean in the Northern Hemisphere, East Asia also contributes the most to DRF and it is the second-largest contributor to incremental IRF of sulfate following DMS. Over land in the Southern Hemisphere, emissions from Southern Africa and South America control DRF, whereas incremental IRF are largely attributed to sources from South America, DMS and PAN (Pacific/Australia/New Zealand). Over ocean in the Southern Hemisphere, both sulfate DRF and incremental IRF are dominated by DMS emissions.

Figure 11 shows the seasonal and annual global DRF and incremental IRF efficiencies of sulfate. (Table S6 gives values.) Global DRF efficiency of a source region is defined as the global DRF of sulfate originating from the source region/sector divided by the total sulfur emissions from that region/sector. The global DRF efficiency treats the whole globe as a receptor region, as opposed to a specific region in the regional concentration efficiency definition, considering that aerosol climatic impacts are on a global scale whereas air quality impacts are more important on a regional scale. As the DRF is more closely related to sulfate bur- den, global sulfate burden efficiencies are also provided in Table S7. The global DRF efficiency for total sulfur emissions is $4.8 \mathrm{~mW} \mathrm{~m}^{-2}\left(\mathrm{Tg} \mathrm{S} \mathrm{yr}^{-1}\right)^{-1}$. The Middle East, North Africa and Southern Africa present high DRF efficiencies, as a result of both long aerosol lifetime and strong tropical insolation. These source regions also have high global burden efficiencies.

The global IRF efficiency of a source region is calculated as the global contribution of sulfate incremental IRF divided by the changes (i.e., $20 \%$ reduction) in sulfur emissions in that region. Unlike the DRF efficiencies, IRF efficiencies are higher over or near ocean regions, with a global IRF efficiency of $25.0 \mathrm{~mW} \mathrm{~m}^{-2}\left(\mathrm{Tg} \mathrm{S} \mathrm{yr}^{-1}\right)^{-1}$ for the global total $20 \%$ of sulfur emissions. PAN and DMS have the largest IRF efficiencies because PAN has a relatively clean environment compared to other regions and DMS is emitted over clean oceans. Cloud properties are more susceptible to aerosol perturbations in a more pristine environment. Although the background aerosols in South America are not so low, sulfate originating from this region has a large contribution to sulfate over oceans of the Southern Hemisphere, explaining a large IRF efficiency from that region.

In addition to the incremental IRF and efficiency, we also calculated the anthropogenic sulfate IRF and its efficiency between present-day and preindustrial conditions with an ad- 

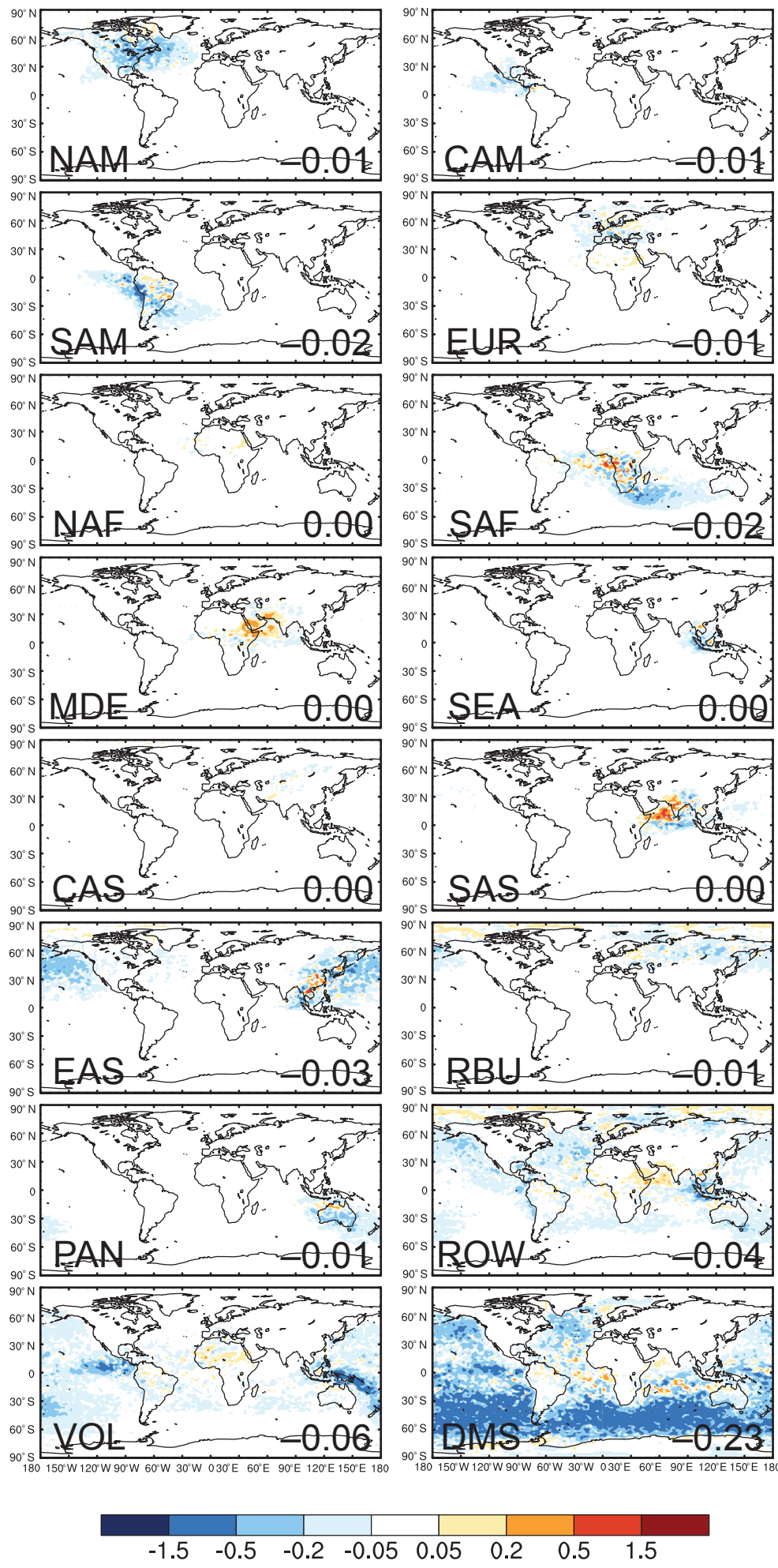

Sulfate indirect radiative forcing $\left(\mathrm{W} \mathrm{m}^{-2}\right)$

Figure 10. Spatial distribution of responses of annual mean indirect radiative forcing of sulfate (IRF, $\mathrm{W} \mathrm{m}^{-2}$ ) to a $20 \%$ reduction in sulfur emissions (standard simulation - simulation with $20 \%$ emission reduction). Regional contributions are calculated as a scaled total incremental IRF in each grid cell by the ratio of the source contribution to total sulfate mass concentration reduction averaged from the surface layer to $850 \mathrm{hPa}$. Regional mean contributions to global incremental IRF of sulfate are shown at the bottom right of each panel. 

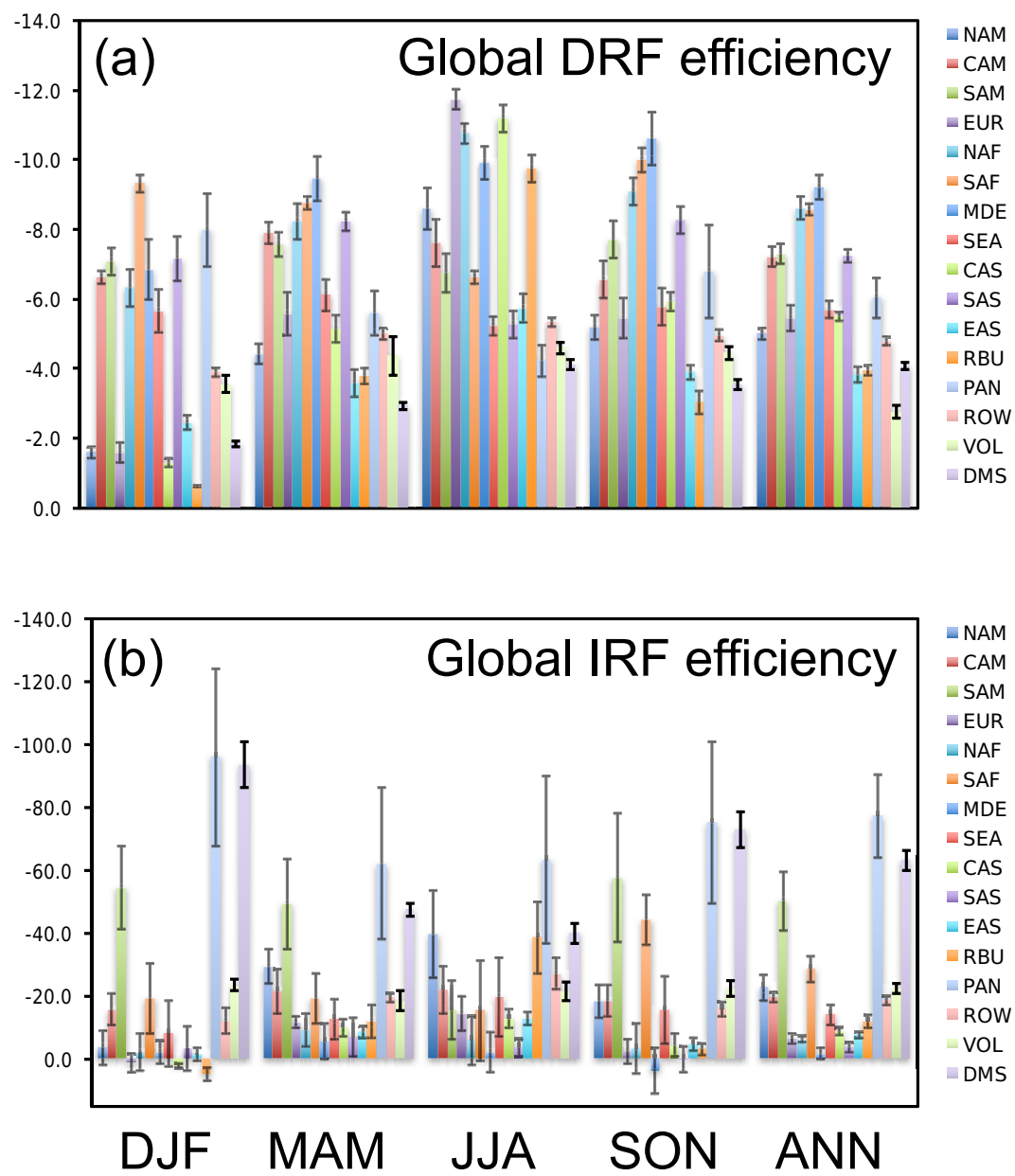

Figure 11. Seasonal and annual mean global sulfate (a) direct and (b) indirect radiative forcing efficiency $\left(\mathrm{mW} \mathrm{m}^{-2}\left(\mathrm{Tg} \mathrm{S} \mathrm{yr}^{-1}\right)^{-1}\right)$ of the 16 tagged source regions/sectors. The sulfate radiative efficiency is defined as the global sulfate radiative forcing divided by the corresponding scaled annual sulfur emissions (seasonal emissions multiplied by 4). Error bars indicate $1 \sigma$ of mean values during years $2010-2014$.

ditional simulation, in which anthropogenic $\mathrm{SO}_{2}$ emissions are fixed at the 1850 level, and compared these values with those from the $20 \%$ sulfur emission reduction simulation in Table S8. The modeled annual and global mean anthropogenic sulfate IRF here is $-0.74 \mathrm{~W} \mathrm{~m}^{-2}$, which is comparable to $-0.45 \pm 0.5 \mathrm{~W} \mathrm{~m}^{-2}$ of IRF for total anthropogenic aerosols from IPCC (2013). The anthropogenic IRF contributed from individual source regions is about 3-6 times larger than the incremental IRF, in agreement with about 5 times more reduction in $\mathrm{SO}_{2}$ emissions in the preindustrial simulation than in the $20 \%$ sulfur emission reduction simulation. The forcing efficiencies are roughly similar between the incremental and the anthropogenic IRF, indicating a nearly linear relationship between $\mathrm{SO}_{2}$ emissions and sulfate IRF, except for the Middle East and South Asia, where concentrated dust and its variability may strongly influence cloud properties and therefore sulfate IRF. Figure S11 shows the anthropogenic sulfate IRF efficiencies that are calculated based on anthropogenic IRF from the present-day and prein- dustrial conditions simulations. The values are similar to the incremental IRF efficiencies, further validating the robust results from the decomposed regional IRF with the sulfur source-tagging technique.

For comparison, Table S8 also includes the incremental DRF calculated with the same simulations for the incremental IRF and the standard anthropogenic DRF between present-day and preindustrial conditions, as well as their efficiencies. The forcing efficiencies are also similar between the incremental and the standard anthropogenic DRF. The IRF and its efficiencies are much higher than those of DRF for sources over or around clean oceanic regions (e.g., DMS, volcanic $\mathrm{SO}_{2}$, emissions from Australia and South America), but much lower for regions with high emissions (e.g., the Middle East, South Asia). 


\section{Conclusions and discussions}

A sulfur source-tagging technique is implemented in Community Atmosphere Model (CAM) of the Community Earth System Model (CESM) and used in this study to examine source-receptor relationships of sulfate concentrations, DRF and IRF originating from 16 regions/sectors (North America, Central America, South America, Europe, North Africa, Southern Africa, the Middle East, Southeast Asia, Central Asia, South Asia, East Asia, RBU, PAN, ROW, VOL and DMS) for 2010-2014. The anthropogenic emissions came from the CEDS inventory developed for the CMIP6.

Near-surface sulfate concentrations are mostly contributed by local emissions in regions with high emissions, such as eastern US, Southern Africa, South Asia and eastern China, where local source contributions exceed $80 \%$. Over regions with relatively low $\mathrm{SO}_{2}$ emissions, the near-surface sulfate concentrations are primarily attributed to non-local sources from long-range transport.

The source-receptor relationships have strong seasonal variations. The export of sulfate from Europe contributes to $16-20 \%$ of near-surface sulfate concentrations over North Africa, RBU and Central Asia in all seasons. Sulfate from the Middle East is effectively transported to the surrounding receptor regions and accounts for $15-24 \%$ of sulfate concentrations over North Africa, Southern Africa and Central Asia in DJF and SON, and $19 \%$ over South Asia in MAM. Sources in RBU account for $21-42 \%$ of sulfate concentrations over Central Asia, with a peak contribution in JJA. Northerly winds over East Asia in DJF and SON associated with East Asian winter monsoon transport sulfate from highly polluted eastern China to Southeast Asia, accounting for about $50 \%$ of near-surface sulfate concentrations over Southeast Asia. East Asia also contributes $15 \%$ to the nearsurface sulfate over RBU in JJA and $11 \%$ over North America in MAM. The transport of sulfate from South Asia contributes 11-24\% of near-surface sulfate over Southeast Asia in DJF and MAM. Regional sulfate concentration efficiencies are higher over regions with dry atmospheric conditions and less export, suggesting that the lifetime of aerosols mainly driven by wet deposition, together with regional export, is important in determining the regional air quality.

The simulated global total sulfate DRF is $-0.42 \mathrm{~W} \mathrm{~m}^{-2}$, with $-0.31 \mathrm{~W} \mathrm{~m}^{-2}$ contributed by anthropogenic sulfate and $-0.11 \mathrm{~W} \mathrm{~m}^{-2}$ contributed by natural sulfate. DMS has the largest contribution to the global sulfate DRF, followed by East Asia, ROW and South Asia. In the Southern Hemisphere, DMS contributes $17-84 \%$ to the seasonal total sulfate DRF. In the Northern Hemisphere tropics, East Asia, South Asia, ROW and DMS exert similar contributions of $10-20 \%$. East Asia has the largest contribution of 20-30\% over the Northern Hemisphere mid- and high latitudes, followed by South Asia and ROW.

Sulfate incremental IRF is estimated using an additional simulation in which sulfur emissions are reduced by $20 \%$.
The difference in cloud radiative forcing between the control simulation and this second simulation gives the sulfate incremental IRF of the last $20 \%$ of sulfur emissions, which is $-0.44 \mathrm{~W} \mathrm{~m}^{-2}$ globally. DMS has the largest contribution, explaining $-0.23 \mathrm{~W} \mathrm{~m}^{-2}$ of the global sulfate incremental IRF, because of the clean marine background conditions, followed by $-0.06 \mathrm{~W} \mathrm{~m}^{-2}$ from volcanic emissions. The tagging method, combined with regional decomposition, provides a computationally efficient method of quantifying regional IRF that has a higher signal to noise as compared to regional perturbation simulations.

The Middle East, North Africa and Southern Africa have high global DRF efficiencies, due to both longer aerosol lifetimes (from low precipitation) and strong insolation. Regions in the Southern Hemisphere with low background aerosols have stronger global IRF efficiencies than those over the polluted Northern Hemisphere, because cloud properties are more susceptible to aerosol perturbations in a more pristine environment.

Note that although simulated near-surface sulfate concentrations are in agreement with observed values at the IMPROVE sites over North America and at the EANET sites over part of East and Southeast Asia, the model strongly underestimates sulfate concentrations by $-54 \%$ in China, compared to site observations from the CAWNET network. Comparison of column-integrated $\mathrm{SO}_{2}$ between model simulation and OMI satellite data shows a possible overestimation of $\mathrm{SO}_{2}$ in the model. The simulated $\mathrm{SO}_{2}$ near-surface concentrations, however, are underestimated by $25 \%$ compared to observations over 13 sites in China, suggesting a large bias in satellite retrievals or too much $\mathrm{SO}_{2}$ simulated at higher altitudes. The model $\mathrm{SO}_{2}$ concentrations over downwind regions of China are underestimated by $45 \%$, indicating that the transport of $\mathrm{SO}_{2}$ from China is probably underestimated in the model. A less efficient transformation from $\mathrm{SO}_{2}$ to sulfate could also lead to the underestimation of sulfate in the model. The underestimation of sulfate over China could lead to the underestimation of contributions from East Asia to remote sulfate concentrations, global DRF and incremental IRF, as well as their efficiencies.

Table S9 compares the annual sulfate radiative forcing efficiencies simulated in this study to those in previous multimodel studies (Yu et al., 2013; Bellouin et al., 2016; Stjern et al., 2016). As in the previous studies, the DRF efficiency is calculated as the response of global DRF to a $20 \%$ reduction in local emissions divided by the $20 \%$ of sulfur emissions based on two separate simulations rather than $100 \%$ of local emissions in a single simulation (Table S6). The efficiencies based on the $20 \%$ emission reduction are very similar to those of the $100 \%$ emission reduction, indicating a nearly linear relationship between sulfate DRF and emissions. Compared to Yu et al. (2013) and Stjern et al. (2016), the DRF efficiencies in this study are around the lower bound for all source regions. Another multi-model intercomparison study also reported a lower sulfate DRF simulated in CAM5 com- 
pared to other models (Myhre et al., 2013). The difference in DRF efficiencies likely arises from differences in the estimates of aerosol optical properties. With aerosol-cloud interactions included, the total radiative forcing efficiencies in this study are similar to the best estimates provided by Bellouin et al. (2016). The global IRF in CAM5 was also found to be larger than other models in a nine-model intercomparison study, which was attributed to a strong aerosol-induced cloud scattering (Zelinka et al., 2014).

Data availability. All the emissions data sets used in this study can be obtained from https://pcmdi.llnl.gov/projects/input4mips (Hoesly et al., 2017; van Marle et al., 2017). The sulfate data sets are available from http://vista.cira.colostate.edu/IMPROVE/ for IMPROVE sites, http://www.eanet.asia for EANET sites and http: //www.emep.int for EMEP sites. The OMI satellite-derived total column burden of $\mathrm{SO}_{2}$ can be downloaded from http://disc.sci. gsfc.nasa.gov/Aura/data-holdings/OMI/omso2e_v003.shtml ( $\mathrm{Li}$ et al., 2013). The CESM model is publicly available at http://www. cesm.ucar.edu/models/cesm1.2/ (Hurrell et al., 2013). Our model results can be made available through the National Energy Research Scientific Computing Center (NERSC) servers upon request.

\section{The Supplement related to this article is available online at https://doi.org/10.5194/acp-17-8903-2017-supplement.}

Competing interests. The authors declare that they have no conflict of interest.

Acknowledgements. This research was supported by the National Aeronautics and Space Administration's Atmospheric Composition: Modeling and Analysis Program (ACMAP), award NNH15AZ64I. We also acknowledge support from the US Department of Energy (DOE), Office of Science, Biological and Environmental Research as part of the Regional and Global Climate Modeling program. The Pacific Northwest National Laboratory is operated for DOE by Battelle Memorial Institute under contract DE-AC05-76RLO1830. The CESM project was supported by the National Science Foundation and the DOE Office of Science. The National Energy Research Scientific Computing Center (NERSC) provided computational resources.

Edited by: Qiang Zhang

Reviewed by: two anonymous referees

\section{References}

Abdul-Razzak, H. and Ghan, S. J.: A parameterization of aerosol activation, 2. Multiple aerosol types, J. Geophys. Res., 105, 68376844, https://doi.org/10.1029/1999JD901161, 2000.
Bellouin, N., Baker, L., Hodnebrog, Ø., Olivié, D., Cherian, R., Macintosh, C., Samset, B., Esteve, A., Aamaas, B., Quaas, J., and Myhre, G.: Regional and seasonal radiative forcing by perturbations to aerosol and ozone precursor emissions, Atmos. Chem. Phys., 16, 13885-13910, https://doi.org/10.5194/acp-16-138852016, 2016.

Bergin, M. S., West, J. J., Keatingm, T. J., and Russell, A. G.: Regional atmospheric pollution and transboundary air quality management, Annu. Rev. Environ. Res., 30, 1-37, https://doi.org/10.1146/annurev.energy.30.050504.144138, 2005.

Boucher, O., Randall, D., Artaxo, P., Bretherton, C., Feingold, G., Forster, P., Kerminen, V.-M., Kondo, Y., Liao, H., Lohmann, U., Rasch, P., Satheesh, S. K., Sherwood, S., Stevens, B., and Zhang, X. Y.: Clouds and Aerosols, in: Climate Change 2013: The Physical Science Basis, Contribution of Working Group I to the Fifth Assessment Report of the Intergovernmental Panel on Climate Change, edited by: Stocker, T. F., Qin, D., Plattner, G.K., Tignor, M., Allen, S. K., Boschung, J., Nauels, A., Xia, Y., Bex, V., and Midgley, P. M., Cambridge University Press, Cambridge, United Kingdom and New York, NY, USA, 571-658, https://doi.org/10.1017/CBO9781107415324.016, 2013.

Chin, M., Diehl, T., Ginoux, P., and Malm, W.: Intercontinental transport of pollution and dust aerosols: implications for regional air quality, Atmos. Chem. Phys., 7, 5501-5517, https://doi.org/10.5194/acp-7-5501-2007, 2007.

Driscoll, C. T., Lawrence, G. B., Bulger, A. J., Butler, T. J., Cronan, C. S., Eagar, C., Lambert, K. F., Likens, G. E., Stoddard, J. L., and Weathers, K. C.: Acidic deposition in the Northeastern United States: sources and inputs, ecosystem effects, and management strategies, BioScience, 51, 180-198, https://doi.org/10.1641/00063568(2001)051[0180:ADITNU]2.0.CO;2, 2001.

Fajersztajn, L., Veras, M., Barrozo, L. V., and Saldiva, P.: Air pollution: a potentially modifiable risk factor for lung cancer, Nat. Rev. Cancer, 13, 674-678, https://doi.org/10.1038/nrc3572, 2013.

Ghan, S. J.: Technical Note: Estimating aerosol effects on cloud radiative forcing, Atmos. Chem. Phys., 13, 9971-9974, https://doi.org/10.5194/acp-13-9971-2013, 2013.

Gong, D.-Y., Wang, W., Qian, Y., Bai, W., Guo, Y., and Mao, R.: Observed holiday aerosol reduction and temperature cooling over East Asia, J. Geophys. Res.-Atmos., 119, 6306-6324, https://doi.org/10.1002/2014JD021464, 2014.

Hadley, O. L., Ramanathan, V., Carmichael, G. R., Tang, Y., Corrigan, C. E., Roberts, G. C., and Mauger, G. S., Trans-Pacific transport of black carbon and fine aerosol $(\mathrm{D}<2.5 \mu \mathrm{m})$ into North America, J. Geophys. Res., 112, D05309, https://doi.org/10.1029/2006JD007632, 2007.

He, H., Li, C., Loughner, C. P., Li, Z., Krotkov, N. A., Yang, K., Wang, L., Zheng, Y., Bao, X., Zhao, G., and Dickerson, R. R.: $\mathrm{SO}_{2}$ over central China?: Measurements, numerical simulations and the tropospheric sulfur budget, J. Geophys. Res., 117, D00K37, https://doi.org/10.1029/2011JD016473, 2012.

Heald, C. L., Jacob, D. J., Park, R. J., Alexander, B., Fairlie, T. D., Yantosca, R. M., and Chu, D. A.: Transpacific transport of Asian anthropogenic aerosols and its impact on surface air quality in the united states, J. Geophys. Res.-Atmos., 111, D14310, https://doi.org/10.1029/2005JD006847, 2006. 
Hoesly, R. M., Smith, S. J., Feng, L., Klimont, Z., JanssensMaenhout, G., Pitkanen, T., Seibert, J. J., Vu, L., Andres, R. J., Bolt, R. M., Bond, T. C., Dawidowski, L., Kholod, N., Kurokawa, J.-I., Li, M., Liu, L., Lu, Z., Moura, M. C. P., O'Rourke, P. R., and Zhang, Q.: Historical (1750-2014) anthropogenic emissions of reactive gases and aerosols from the Community Emission Data System (CEDS), Geosci. Model Dev. Discuss., https://doi.org/10.5194/gmd-2017-43, in review, 2017.

Hurrell, J. W., Holland, M. M., Gent, P. R., Ghan, S., Kay, J. E., Kushner, P. J., Lamarque, J. F., Large, W. G., Lawrence, D., Lindsay, K., Lipscomb, W. H., Long, M. C., Mahowald, N., Marsh, D. R., Neale, R. B., Rasch, P., Vavrus, S., Vertenstein, M., Bader, D., Collins, W. D., Hack, J. J., Kiehl, J., and Marshall, S.: The Community Earth System Model A Framework for Collaborative Research, B. Am. Meteorol. Soc., 94, 1339-1360, 2013.

IPCC: Climate Change 2013: the Physical Science Basis. Contribution of Working Group I to the Fifth Assessment Report of the Intergovernmental Panel on Climate Change. Cambridge University Press, Cambridge, United Kingdom and New York, NY, USA, p. 1535, 2013.

Jacob, D. J., Crawford, J. H., Kleb, M. M., Connors, V. S., Bendura, R. J., Raper, J. L., Sachse, G. W., Gille, J. C., Emmons, L., and Heald, C. L.: Transport and chemical evolution over the Pacific (TRACE-P) aircraft mission: design, execution, and first results, J. Geophys. Res.-Atmos., 108, 1-19, https://doi.org/10.1029/2002JD003276, 2003.

Jaffe, D., McKendry, I., Anderson, T., and Price, H.: Six "new" episodes of transpacific transport of air pollutants, Atmos. Environ., 37, 391-404, https://doi.org/10.1016/S13522310(02)00862-2, 2003.

Kasoar, M., Voulgarakis, A., Lamarque, J.-F., Shindell, D. T., Bellouin, N., Collins, W. J., Faluvegi, G., and Tsigaridis, K.: Regional and global temperature response to anthropogenic $\mathrm{SO}_{2}$ emissions from China in three climate models, Atmos. Chem. Phys., 16, 9785-9804, https://doi.org/10.5194/acp-169785-2016, 2016.

Koren, I., Dagan, G., and Altaratz, O.: From aerosol-limited to invigoration of warm convective clouds, Science, 344, 1143-1146, https://doi.org/10.1126/science.1252595, 2014.

Li, C., Joiner, J., Krotkov, N. A., and Bhartia, P. K.: A fast and sensitive new satellite $\mathrm{SO}_{2}$ retrieval algorithm based on principal component analysis: Application to the ozone monitoring instrument, Geophys. Res. Lett., 40, 6314-6318, https://doi.org/10.1002/2013GL058134, 2013.

Li, G., Bei, N., Cao, J., Huang, R., Wu, J., Feng, T., Wang, Y., Liu, S., Zhang, Q., Tie, X., and Molina, L. T.: A possible pathway for rapid growth of sulfate during haze days in China, Atmos. Chem. Phys., 17, 3301-3316, https://doi.org/10.5194/acp17-3301-2017, 2017.

Liu, J., Mauzerall, D. L., and Horowitz, L. W.: Source-receptor relationships between East Asian sulfur dioxide emissions and Northern Hemisphere sulfate concentrations, Atmos. Chem. Phys., 8, 3721-3733, https://doi.org/10.5194/acp-8-3721-2008, 2008.

Liu, J. F. and Mauzerall, D. L.: Potential influence of intercontinental transport of sulfate aerosols on air quality, Environ. Res. Lett., 2, 045029, https://doi.org/10.1088/17489326/2/4/045029, 2007.
Liu, J. F., Mauzerall, D. L., Horowitz, L. W., Ginoux, P., and Fiore, A. M.: Evaluating inter-continental transport of fine aerosols: 1. Methodology, global aerosol distribution and optical depth, Atmos. Environ., 43, 4327-4338, https://doi.org/10.1016/j.atmosenv.2009.03.054, 2009.

Liu, X., Easter, R. C., Ghan, S. J., Zaveri, R., Rasch, P., Shi, X., Lamarque, J.-F., Gettelman, A., Morrison, H., Vitt, F., Conley, A., Park, S., Neale, R., Hannay, C., Ekman, A. M. L., Hess, P., Mahowald, N., Collins, W., Iacono, M. J., Bretherton, C. S., Flanner, M. G., and Mitchell, D.: Toward a minimal representation of aerosols in climate models: description and evaluation in the Community Atmosphere Model CAM5, Geosci. Model Dev., 5, 709-739, https://doi.org/10.5194/gmd-5-709-2012, 2012.

Lohmann, U. and Feichter, J.: Global indirect aerosol effects: A review, Atmos. Chem. Phys., 5, 715-737, https://doi.org/10.5194/acp-5-715-2005, 2005.

Lu, Z., Streets, D. G., Zhang, Q., Wang, S., Carmichael, G. R., Cheng, Y. F., Wei, C., Chin, M., Diehl, T., and Tan, Q.: Sulfur dioxide emissions in China and sulfur trends in East Asia since 2000, Atmos. Chem. Phys., 10, 6311-6331, https://doi.org/10.5194/acp-10-6311-2010, 2010.

Ma, P.-L., Rasch, P. J., Wang, H., Zhang, K., Easter, R. C., Tilmes, S., Fast, J. D., Liu, X., Yoon, J.-H., and Lamarque, J.-F.: The role of circulation features on black carbon transport into the Arctic in the Community Atmosphere Model version 5 (CAM5), J. Geophys. Res.-Atmos., 118, 4657-4669, https://doi.org/10.1002/jgrd.50411, 2013.

Martin, L. R., and Damschen, D. E.: Aqueous oxidation of sulfurdioxide by hydrogen-peroxide at low pH, Atmos. Environ., 15, 1615-1621, https://doi.org/10.1016/0004-6981(81)90146-3, 1981.

McCoy, D. T., Bender, F. A.-M., Mohrmann, J. K. C., Hartmann, D. L., Wood, R., and Grosvenor, D. P.: The global aerosolcloud first indirect effect estimated using MODIS, MERRA, and AeroCom, J. Geophys. Res.-Atmos., 122, 1779-1796, https://doi.org/10.1002/2016JD026141, 2017.

McLinden, C. A, Fioletov, V. E., Shephard, M., Krotkov, N., Li, C., Martin, R. V., Moran, M. D., and Joiner, J.: Space-based detection of missing sulfur dioxide sources of global air pollution, Nat Geosci., 9, 496-500, https://doi.org/10.1038/ngeo2724, 2016.

Morrison, H. and Gettelman, A.: A new two-moment bulk stratiform cloud microphysics scheme in the Community Atmosphere Model, version 3 (CAM3), Part I: Description and numerical tests, J. Clim., 21, 3642-3659, https://doi.org/10.1175/2008JCLI2105.1, 2008.

Myhre, G., Samset, B. H., Schulz, M., Balkanski, Y., Bauer, S., Berntsen, T. K., Bian, H., Bellouin, N., Chin, M., Diehl, T., Easter, R. C., Feichter, J., Ghan, S. J., Hauglustaine, D., Iversen, T., Kinne, S., Kirkevåg, A., Lamarque, J.-F., Lin, G., Liu, X., Lund, M. T., Luo, G., Ma, X., van Noije, T., Penner, J. E., Rasch, P. J., Ruiz, A., Seland, Ø., Skeie, R. B., Stier, P., Takemura, T., Tsigaridis, K., Wang, P., Wang, Z., Xu, L., Yu, H., Yu, F., Yoon, J.-H., Zhang, K., Zhang, H., and Zhou, C.: Radiative forcing of the direct aerosol effect from AeroCom Phase II simulations, Atmos. Chem. Phys., 13, 1853-1877, https://doi.org/10.5194/acp13-1853-2013, 2013.

Neale, R. B., Chen, C.-C., Gettelman, A., Lauritzen, P. H., Park, S., Williamson, D. L., Conley, A. J., Garcia, R., Kinnison, D., Lamarque, J.-F., Marsh, D., Mills, M., Smith, A. K., Tilmes, S., 
Vitt, F., Morrison, H., Gameron-Smith, P., Collins, W. D., Iacono, M. J., Easter, R. C., Ghan, S. J., Liu, X., Rasch, P. J., and Taylor, M. A.: Description of the NCAR Community Atmosphere Model (CAM5), NCAR Technical Note NCAR/TN-486+STR, 275 pp., 2012.

Park, R. J., Jacob, D. J., Field, B. D., Yantosca, R. M., and Chin, M.: Natural and transboundary pollution influences on sulfate-nitrate-ammonium aerosols in the United States: Implications for policy, J. Geophys. Res.-Atmos., 109, D15204, https://doi.org/10.1029/2003JD004473, 2004.

Pham, M., Boucher, O., and Hauglustaine, D.: Changes in atmospheric sulfur burdens and concentrations and resulting radiative forcings under IPCC SRES emission scenarios for 1990-2100, J. Geophys. Res.-Atmos., 110, D06112, https://doi.org/10.1029/2004JD005125, 2005.

Prechtel, A., Alewell, C., Armbruster, M., Bittersohl, J., Cullen, J. M., Evans, C. D., Helliwell, R., Kopacek, J., Marchetto, A., Matzner, E., Meesenburg, H., Moldan, F., Moritz, K., Vesely, J., and Wright, R. F.: Response of sulphur dynamics in European catchments to decreasing sulphate deposition, Hydrol. Earth Sys. Sci., 5, 311-325, https://doi.org/10.5194/hess-5-311-2001, 2001.

Qian, Y., Gustafson Jr., W. I., and Fast, J. D.: An investigation of the sub-grid variability of trace gases and aerosols for global climate modeling, Atmos. Chem. Phys., 10, 6917-6946, https://doi.org/10.5194/acp-10-6917-2010, 2010.

Rienecker, M. M., Suarez, M. J., Gelaro, R., Todling, R., Bacmeister, J., Liu, R., Bosilovich, M. G., Schubert, S. D., Takacs, L., Kim, G-K, Bloom, S., Chen, J., Collins, D., Conaty, A., da Silva, A., Gu, W., Joiner, J., Koster, R. D., Lucchesi, R., Molod, A., Owens, T., Pawson, S., Pegion, P., Redder, C. R., Reichle, R., Robertson, F. R., Ruddick, A. G., Sienkiewicz, M., and Woollen, J.: MERRA: NASA's Modern-Era Retrospective Analysis for Research and Applications, J. Clim., 24, 3624-3648, 2011.

Rosenfeld, D., Sherwood, S., Wood, R., and Donner, L.: Climate effects of aerosol-cloud interactions, Science, 343, 379-380, https://doi.org/10.1126/science.1247490, 2014.

Shindell, D., Kuylenstierna, J. C. I., Vignati, E., van Dingenen, R., Amann, M., Klimont, Z., Anenberg, S. C., Muller, N., Janssens-Maenhout, G., Raes, F., Schwartz, J., Faluvegi, G., Pozzoli, L., Kupiainen, K., Höglund-Isaksson, L., Emberson, L., Streets, D., Ramanathan, V., Hicks, K., Oanh, N. T. K., Milly, G., Williams, M., Demkine, V., and Fowler, D.: Simultaneously Mitigating Near-Term Climate Change and Improving Human Health and Food Security, Science, 335, 183-189, https://doi.org/10.1126/science.1210026, 2012.

Shindell, D. T., Lamarque, J.-F., Schulz, M., Flanner, M., Jiao, C., Chin, M., Young, P. J., Lee, Y. H., Rotstayn, L., Mahowald, N., Milly, G., Faluvegi, G., Balkanski, Y., Collins, W. J., Conley, A. J., Dalsoren, S., Easter, R., Ghan, S., Horowitz, L., Liu, X., Myhre, G., Nagashima, T., Naik, V., Rumbold, S. T., Skeie, R., Sudo, K., Szopa, S., Takemura, T., Voulgarakis, A., Yoon, J.-H., and Lo, F.: Radiative forcing in the ACCMIP historical and future climate simulations, Atmos. Chem. Phys., 13, 2939-2974, https://doi.org/10.5194/acp-13-2939-2013, 2013.

Smith, S. J., van Aardenne, J., Klimont, Z., Andres, R. J., Volke, A., and Delgado Arias, S.: Anthropogenic sulfur dioxide emissions: 1850-2005, Atmos. Chem. Phys., 11, 1101-1116, https://doi.org/10.5194/acp-11-1101-2011, 2011.
Stevens, B. and Feingold, G.: Untangling aerosol effects on clouds and precipitation in a buffered system, Nature, 461, 607-613, https://doi.org/10.1038/nature08281, 2009.

Stjern, C. W., Samset, B. H., Myhre, G., Bian, H., Chin, M., Davila, Y., Dentener, F., Emmons, L., Flemming, J., Haslerud, A. S., Henze, D., Jonson, J. E., Kucsera, T., Lund, M. T., Schulz, M., Sudo, K., Takemura, T., and Tilmes, S.: Global and regional radiative forcing from $20 \%$ reductions in $\mathrm{BC}, \mathrm{OC}$ and $\mathrm{SO}_{4}-$ an HTAP2 multi-model study, Atmos. Chem. Phys., 16, 13579 13599, https://doi.org/10.5194/acp-16-13579-2016, 2016.

Streets, D. G., Tsai, N. Y., Akimoto, H., and Oka, K.: Sulfur dioxide emissions in Asia in the period 1985-1997, Atmos. Environ. 34, 4413-4424, https://doi.org/10.1016/S1352-2310(00)001874, 2000.

van Marle, M. J. E., Kloster, S., Magi, B. I., Marlon, J. R., Daniau, A.-L., Field, R. D., Arneth, A., Forrest, M., Hantson, S., Kehrwald, N. M., Knorr, W., Lasslop, G., Li, F., Mangeon, S., Yue, C., Kaiser, J. W., and van der Werf, G. R.: Historic global biomass burning emissions based on merging satellite observations with proxies and fire models (1750-2015), Geosci. Model Dev. Discuss., https://doi.org/10.5194/gmd-2017-32, in review, 2017.

Wang, G., Zhang, R., Gomez, M. E., Yang, L., Levy Zamora, M., Hu, M., Lin, Y., Peng, J., Guo, S., Meng, J., Li, J., Cheng, C., Hu, T., Ren, Y., Wang, Y., Gao, J., Cao, J., An, Z., Zhou, W., Li, G., Wang, J., Tian, P., Marrero-Ortiz, W., Secrest, J., Du, Z., Zheng, J., Shang, D., Zeng, L., Shao, M., Wang, W., Huang, Y., Wang, Y., Zhu, Y., Li, Y., Hu, J., Pan, B., Cai, L., Cheng, Y., Ji, Y., Zhang, F., Rosenfeld, D., Liss, P. S., Duce, R. A., Kolb, C. E., and Molina, M. J.: Persistent sulfate formation from London Fog to Chinese haze, P. Natl. Acad. Sci USA, 113, 13630-13635, https://doi.org/10.1073/pnas.1616540113, 2016.

Wang, H., Easter, R. C., Rasch, P. J., Wang, M., Liu, X., Ghan, S. J., Qian, Y., Yoon, J.-H., Ma, P.-L., and Vinoj, V.: Sensitivity of remote aerosol distributions to representation of cloud-aerosol interactions in a global climate model, Geosci. Model Dev., 6, 765-782, https://doi.org/10.5194/gmd-6-765-2013, 2013.

Wang, H., Rasch, P. J., Easter, R. C., Singh, B., Zhang, R., Ma, P.-L., Qian, Y., Ghan, S. J., and Beagley, N.: Using an explicit emission tagging method in global modeling of source-receptor relationships for black carbon in the Arctic: Variations, sources, and transport pathways, J. Geophys. Res.-Atmos., 119, 12888 12909, https://doi.org/10.1002/2014JD022297, 2014.

Wang, M., Ghan, S., Ovchinnikov, M., Liu, X., Easter, R., Kassianov, E., Qian, Y., and Morrison, H.: Aerosol indirect effects in a multi-scale aerosol-climate model PNNL-MMF, Atmos. Chem. Phys., 11, 5431-5455, https://doi.org/10.5194/acp11-5431-2011, 2011.

Wang, R., Tao, S., Balkanski, Y., Ciais, P., Boucher, O., Liu, J., Piao, S., Shen, H., Vuolo, M. R., and Valari, M.: Exposure to ambient black carbon derived from a unique inventory and high- resolution model, P. Natl. Acad. Sci. USA, 111, 2459-2463, 2014.

$\mathrm{Xu}$, P., Chen, Y. F., and Ye, X. J.: Haze, air pollution, and health in China, Lancet, 382, p. 2067, https://doi.org/10.1016/S01406736(13)62693-8, 2013.

Yang, Y., Liao, H., and Lou, S.: Decadal trend and interannual variation of outflow of aerosols from East Asia: Roles of variations in meteorological parameters and emissions, Atmos. Environ., 100, 141-153, https://doi.org/10.1016/j.atmosenv.2014.11.004, 2015. 
Yang, Y., Wang, H., Smith, S. J., Ma, P.-L., and Rasch, P. J.: Source attribution of black carbon and its direct radiative forcing in China, Atmos. Chem. Phys., 17, 4319-4336, https://doi.org/10.5194/acp-17-4319-2017, 2017.

Yu, H., Remer, L., Chin, M., Bian, H., Tan, Q., Yuan, T., and Zhang, Y.: Aerosols from overseas rival domestic emissions over North America, Science, 337, 566-569, https://doi.org/10.1126/science.1217576, 2012.

Yu, H., Chin, M., West, J. J., Atherton, C. S., Bellouin, N., Bergmann, D., Bey, I., Bian, H., Diehl, T., Forberth, G., Hess, P., Schulz, M., Shindell, D., Takemura, T., and Tan, Q.: A multimodel assessment of the influence of regional anthropogenic emission reductions on aerosol direct radiative forcing and the role of intercontinental transport, J. Geophys. Res.-Atmos., 118, 700-720, https://doi.org/10.1029/2012JD018148, 2013.
Zelinka, M. D., Andrews, T., Forster, P. M., and Taylor, K. E.: Quantifying components of aerosol-cloud-radiation interactions in climate models, J. Geophys. Res.-Atmos., 119, 7599-7615, https://doi.org/10.1002/2014JD021710, 2014.

Zhang, K., Wan, H., Liu, X., Ghan, S. J., Kooperman, G. J., Ma, P.-L., Rasch, P. J., Neubauer, D., and Lohmann, U.: Technical Note: On the use of nudging for aerosol-climate model intercomparison studies, Atmos. Chem. Phys., 14, 8631-8645, https://doi.org/10.5194/acp-14-8631-2014, 2014.

Zhang, X. Y., Wang, Y. Q., Niu, T., Zhang, X. C., Gong, S. L., Zhang, Y. M., and Sun, J. Y.: Atmospheric aerosol compositions in China: spatial/temporal variability, chemical signature, regional haze distribution and comparisons with global aerosols, Atmos. Chem. Phys., 12, 779-799, https://doi.org/10.5194/acp12-779-2012, 2012. 